Review

\title{
Varroa destructor from the Laboratory to the Field: Control, Biocontrol and IPM Perspectives-A Review
}

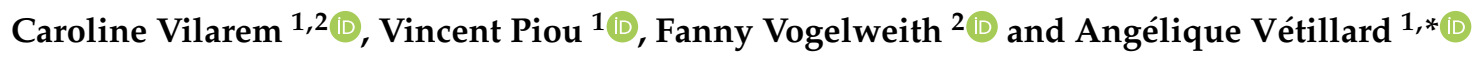 \\ 1 Laboratoire Evolution et Diversité Biologique, UMR5174, CNRS-Université de Toulouse III-IRD, \\ INU Jean-François Champollion, Université Paul Sabatier, 31077 Toulouse, France; \\ caroline.vilarem@m2i-group.fr (C.V.); vincentpiou@live.fr (V.P.) \\ 2 M2i Biocontrol-Entreprise SAS, 46140 Parnac, France; fanny.vogelweith@m2i-group.fr \\ * Correspondence: angelique.vetillard@univ-jfc.fr
}

Citation: Vilarem, C.; Piou, V.; Vogelweith, F.; Vétillard, A. Varroa destructor from the Laboratory to the Field: Control, Biocontrol and IPM Perspectives-A Review. Insects 2021, 12, 800. https://doi.org/10.3390/ insects12090800

Academic Editors: Guillaume Minard and Patricia Gibert

Received: 4 August 2021

Accepted: 2 September 2021

Published: 7 September 2021

Publisher's Note: MDPI stays neutral with regard to jurisdictional claims in published maps and institutional affiliations.

Copyright: (c) 2021 by the authors. Licensee MDPI, Basel, Switzerland. This article is an open access article distributed under the terms and conditions of the Creative Commons Attribution (CC BY) license (https:// creativecommons.org/licenses/by/ $4.0 /)$.
Simple Summary: Varroa destructor is a parasitic organism feeding and living among honeybees. It transmits viruses like the Deformed Wing Virus which can lead to the decline and death of the colony. Many treatments have been developed over the years like formamidine amitraz, pyrethroid tau-fluvalinate, organophosphate coumaphos or even acids like formic and oxalic to control the spread of the mite. However, none of this solution provides long-term sustainability for honeybees and no resistance from $V$. destructor. Therefore, the development of alternative tools remains open. This will require the combination of both laboratory and field results through an integrative approach based on the identification of $V$. destructor health biomarkers. Here we review what has been done and what can be done from the laboratory to the field against the parasitic pressure held on honeybees.

Abstract: Varroa destructor is a real challenger for beekeepers and scientists: fragile out of the hive, tenacious inside a bee colony. From all the research done on the topic, we have learned that a better understanding of this organism in its relationship with the bee but also for itself is necessary. Its biology relies mostly on semiochemicals for reproduction, nutrition, or orientation. Many treatments have been developed over the years based on hard or soft acaricides or even on biocontrol techniques. To date, no real sustainable solution exists to reduce the pressure of the mite without creating resistances or harming honeybees. Consequently, the development of alternative disruptive tools against the parasitic life cycle remains open. It requires the combination of both laboratory and field results through a holistic approach based on health biomarkers. Here, we advocate for a more integrative vision of $V$. destructor research, where in vitro and field studies are more systematically compared and compiled. Therefore, after a brief state-of-the-art about the mite's life cycle, we discuss what has been done and what can be done from the laboratory to the field against $V$. destructor through an integrative approach.

Keywords: Varroa destructor; honeybees; integrated pest management; biocontrol; holistic approach

\section{Introduction}

While honeybees forage, nurse, reproduce, eat, or communicate in an already critical unhealthy environment with pesticides [1], climate change [2] or habitat loss [3], parasites take their chance too [4]. One of them is Varroa destructor, a world major threat against bees [5,6]. After a shift from its original host the Asian bee Apis cerana to the Western honeybee Apis mellifera, it rapidly spread in the 1970s in Europe and in the 1980s in America [5]. It is now observed in both managed and wild A. mellifera [7]. Due to a shorter coevolution time between $A$. mellifera and $V$. destructor [8] as well as fundamental biological differences, the Western honeybee is far more impacted by the mite than the original host [5,9-11].

Why is this ecto-parasite such a threat for $A$. mellifera worldwide? It appears that $V$. destructor is tightly connected to several viruses and especially the DWV (Deformed 
Wing Virus) with its diverse variants DWV-A, DWV-B originally known as VDV-1 and DWV-C [12-14]. This RNA virus is responsible for wing malformations in bees, causing flight incapacities, thus a lack in food collection for the colony but also a threat to pollination $[15,16]$. Assuming the transmission of the virus occurs at the adult stage, no visible symptoms are reported [17] but a shortened lifespan is described [18]. The infection at the larval stage (emphasised through $V$. destructor) induces damage like shortened abdomens, reduced brood nursing and learning deficits $[19,20]$. From a host-parasite perspective, interactions have to be considered not as a duo but as a triangle, highlighting the virus quasispecies which can spread between bees and acari $[17,21-26]$.

Fifty years of intense research about $V$. destructor support an impressive amount of knowledge in order to deal with practical issues: how to reduce the impact of the mite on honeybee populations [27]? It is true that current control methods efficiency for the acari are still debated. Hard chemicals like pyrethroids, formamidine, organophosphate, neonicotinoid, or sulfoximines were or are still used in the field. However, their negative impact on honeybees' cognition is now widely identified and the resistance developed by the mite is part of current knowledge [28,29]. Other solutions were explored too, like drone removal, brood interruption, or breeding programs [30,31]. Soft acaricides such as thymol, hop leaves or acids seem promising for some [32,33] and already trouble making for others [34,35].

As urged by the integrated pest management program (IPM), a more integrative view is compulsory. The goal is not anymore to kill each and every one of them but rather to reduce their impact without harming honeybees and other wild species around. New strategies based on IPM and biocontrol are passionately studied all over the world. Currently, none is adequate to reduce the adverse impact of mites on bees. It is imperative to develop a holistic approach that focuses on the complete understanding of $V$. destructor biology and its tight relationship with its host. Health biomarkers should be determined for the mite and would help to evaluate at sub-lethal level on a long-term period the impact of molecules or biotechnics. This integrative approach involves in silico, in vivo, semi-field and field scales. Our review aims to discuss the latest ideas about control, IPM and biocontrol for $A$. mellifera against $V$. destructor from the laboratory to the field in realistic reproductible and applicable conditions.

\section{Know Your Challenger, Varroa destructor}

\subsection{The Ecto-Parasite's Life Cycle}

A great dynamic for $V$. destructor research has enlightened the domain, giving us new comprehension about the parasite's interaction with its host. The mite's cycle is composed of two distinct phases. The dispersal phase, previously called phoretic phase $[36,37]$ refers to the periods during which the mite feeds, travels on adult honeybees, allows its spermatophores to mature and activates ovaries [38]. The reproductive phase refers to the part of the cycle which takes place within a brood cell, where the parasite feeds on the bee throughout its development (from larvae up to imago). Once the female mite invades a worker brood cell holding a larval bee from 15 to $20 \mathrm{~h}$ before capping [39], within a few hours the oogenesis begins [40] and $60 \mathrm{~h}$ post cell capping the first egg is laid [41]. New borns feed from the hole $(100 \mu \mathrm{m})$ pierced by the mother's chelicerae in the pupa [42,43]. The feeding pit on bee pupae stands open due to anticoagulants from the ecto-parasite saliva and suppression of healing processes $[37,44,45]$. The first born is always a male (haploid) while the following eggs laid are females (diploid). New borns go through several steps of development, from protonymphs to deutonymphs that molt into adult mites (Figure 1). Once they have reached the adult stage (9-10 days after cell capping for the first born female) and until emergence, mating occurs between brother and sisters in case of single infestation [46,47]. Cross-mating are possible when two or more foundresses invade the same cell [48]. Multiple mating events happen within the cell, until the bee reaches its imaginal stages and emerges. At this point, the male dies and the newly fecund females climb on this new born honeybee, along with their mother, to leave the cell as 
well. A new generation is born, and the life cycle of the mite goes on with the dispersal (ex phoretic) phase. Based on artificial experiments and anatomical observations, a female would be able to do a series of seven reproductive phases before it dies [49,50]. A third state is viable during the lifetime of $V$. destructor. Out of the brood cell or off the honeybee body, the female acari moves freely on the surface of the comb [51] and therefore can survive a few hours without a host.

The population dynamics, structure and genetics of the mite are crucial to understand the spreading process as well as their adaptations and resistances [52,53]. Varroa destructor mating biology leads to intense inbreeding with no exchange among lineages in the population while a single foundress invades a brood cell. However, cross-mating events occur with two or more foundresses co-infesting the same cell resulting in more heterozygous loci [54]. In temperate climate like Europe, during spring at the beginning of the season, single infestations happen due to excess of bee brood compared to the number of ecto-parasites. During summer and fall, the number of available brood cell decreases while $V$. destructor population increases, therefore co-infestations occur intensely (Figure 1). Contrary to initial assumptions, the ecto-parasite is thus, genetically diversified with a dynamic structure over time as it varies according to brood availability in the colony [48]. In addition, genetically different incomers arrive with workers drifting from surrounding colonies $[55,56]$. The host seasonal timeline is a key parameter for genetically based resistance toward acaricides [57]. In fact, temporal rotation between incestuous mating and cross-mating are critical in the failure of controlling $V$. destructor. Inbreeding increases the frequency of homozygotes with resistant alleles to molecules even before any cure. According to genetic population dynamics and structure, treatment should occur during cross-mating period [48].

Besides allowing genetic diversity, the cycle and more specifically the synchronicity between $V$. destructor and its host would not be possible without a chemical communication network.

\subsection{Eavesdropping and Hijacking the Hive: V. destructor, the Perfect Scrounger}

Pheromones are known to be a key factor in colony communication, as they maintain the unity and plasticity of the honeybee society [58,59]. In the present work, we will only focus on some semiochemicals thought to be involved in the host-parasite interactions with $V$. destructor, for a better understanding of the challenger biology.

ORIENTATION-Many olfactory signals from adults, brood, or colony matrices have elicited behavioural responses from the mite. For instance, specific blends of fatty acid esters from old bee larvae $[60,61]$ or aliphatic alcohols and aldehydes from cocoons [62] were shown to trigger the arrest or even the attraction of female acari in laboratory conditions. Brood food holds 2-hydroxyhexanoic acid, a volatile blend which also appeals dispersive mites $[59,63]$. Conversely, the mite is blocked by the $\omega$-functionalised fatty acids from royal jelly [64] and the larger amount of methyl oleate in royal cells [65], preventing the parasitisation of queen brood. The ecto-parasite is also blocked and pushed away by two components of the Nasonov pheromone, geraniol and nerolic acid [66] as well as (Z)-8-heptadecene [67]. It turns out that foragers emit more of this semiochemicals and the (Z)-8-heptadecene than nurses. Therefore, it partially explains why dispersal mites are able to choose nurses over foragers [68,69].

Even $V$. destructor movements across the colony are primarily oriented through volatile compounds catched by their chemosensory organs located in forelegs [70]. Nganso et al., (2020) [71] demonstrated by mechanically blocking them with nail polish that the mite has lower ability to select and identify a suitable host to reproduce.

REPRODUCTION-In the dark environment of the capped cell, the male acari has to recognise and mate specifically with the mature unmated females. The female actually emits a volatile sexual pheromone, composed of oleic acid, palmitic acid, stearic acid and their ethyl esters which attracts the male through its tarsal sensory pits and triggers its courtship behaviour $[72,73]$. The youngest daughter seems to be always the favourite 
choice of the male because the emission of the sexual pheromone is stronger in young and reduced in older females [72]. In the same way, once the mite is inside a capped brood cell, it is the shift in the fatty acid ester compound produced by the bee pupa (a decrease of ethyl esters and an increase of methyl esters) that initiates the reproduction and egg laying through vitellogenin induction $[74,75]$. Even the sex determination seems to be driven by bee pheromones as Garrido and Rosenkrank [76] showed. In that case, fatty acid esters volatile signal triggers a male egg laying by the foundress. Supporting the hypothesis of a complex chemical environment ruling $V$. destructor behaviour, Frey et al. [75] demonstrated that artificially inserted mites with methyl esters compound stop reproduction. Plettner et al. [59] hypothesised that this signal alone could indicate to the mite that the bee pupa development is too advanced for the offspring to reach adulthood before the honeybee emergence.

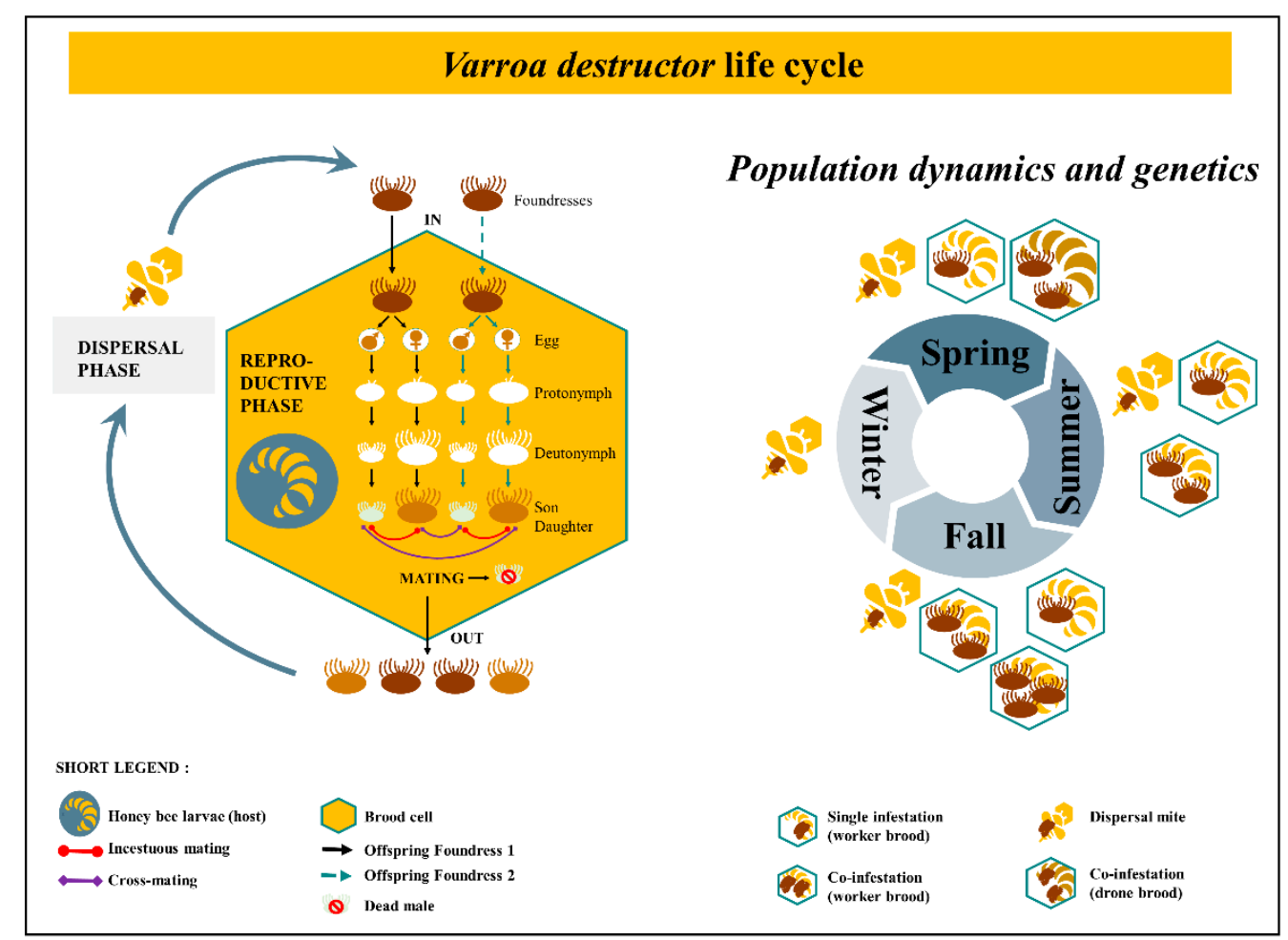

Figure 1. Varroa destructor life cycle and its population dynamics throughout the year. On the left, the two phases of the ecto-parasite cycle. The black line is in case of single infestation, the dashed line is in addition of the black one, thus in case of co-infestation in a brood cell. Inside the brood cell, the foundress laid eggs which go through several steps from protonymph to deutonymph until becoming a new daughter and son. On the right, the pattern of infestation over time. The balance between the number of brood available and the number of ecto-parasites in the colony influence the genetic diversity. Varroa destructor mating biology leads to intense inbreeding with no exchange among lineages in the population while a single foundress invades a brood cell in spring. Co-infestation happens in drone brood cell early in the year. However, cross-mating events occur around summer and fall with two or more foundresses co-infesting the same cell resulting in more heterozygous loci [54]. Contrary to assumptions, the ecto-parasite is genetically diversified with a dynamic structure over time [48].

CAMOUFLAGE_-Varroa destructor has not only chemosensing skills but also undertakes chemical mimicry to influence its host [37,77]. The mite avoids recognition by worker bees that would clean the infested cell or clear their nestmate body carrying acari. As a result, $V$. destructor hijacks host communication signals to bypass exposure [73]. Indeed, the ecto-parasite and honeybees, whatever the developmental stage, share a typical pattern of alkane like pentacosane or heptacosane [78]. In fact, Kather et al., (2015) [79] demonstrated 
that $V$. destructor is unable to biosynthesise host compounds itself (e.g., chemical mimicry) but instead requires direct access to the cuticle for odour passive acquisition (e.g., chemical camouflage) [80]. This camouflage mechanism is extremely plastic and takes only up to $9 \mathrm{~h}$ after host shifting during the reproductive but also dispersal phases.

According to the period and the hive environment, the behaviour of $V$. destructor is quite different and extremely adaptive [81]. At low mites abundance in the colony, acari seem to prefer nurse bees over foragers or new born bees [82], based on differential pheromonal signatures between nurses and foragers. Yet, the mite can passively modify the hydrocarbon cuticle of its host according to colony infestation levels. At high infestation levels, nurses and foragers, less discernible by their different cuticular hydrocarbons, are equally appealing to $V$. destructor, thus promoting the exploration of new bee colonies [83].

This natural drifting of mites between colonies is one of the factors which increases the deleterious effect of the ecto-parasite on bee populations, especially through viral transmission. The biology of the ecto-parasite is indeed not complete without the study of its viruses like the Deformed Wing Virus.

\subsection{Varroa destructor and DWV-A Cut-Throat Association to Bees}

The host-parasite relationship between honeybees and the ecto-parasite is more complex than a duo and takes a third dimension associated with viruses like the DWV. This multipartite interaction is not fully understood. The ecto-parasite plays a central role in the recent expansion of the DWV [16]. It turned this originally benign virus, showing relatively asymptomatic infection, to a highly virulent virus associated with disease symptoms and colony losses [84-86].

Varroa destructor spread also made an impact on the virus genetics and resulted in selection of virulent variants of DWV [87-89]. A particular DWV variant, namely DWV-B, infects the gut epithelium and salivary glands of the ecto-parasite [24], establishing it as a biological virus vector since it multiplies inside the vector $[17,25,26]$. Furthermore, $V$. destructor enhances the development of DWV level in the European honeybee through a saliva protein [22], the same that is toxic for A. cerana worker larvae. Equally important, the predator-prey theory developed by Volterra seems to apply in this triangle connection [90]. The haemolymph punction, that could be associated with the parasitisation, destabilises the immune system, accelerates the immunosuppression and causes explosive replication of the DWV in infected bees [91,92].

What are the effects of DWV on $V$. destructor physiology? Few studies explored the direct impact of the virus on the mite for itself. The main reason is due to the recent advances which showed that $V$. destructor is not only a carrier but as well an amplificator of the virus. One of these studies localised the DWV in the ecto-parasite synganglion questioning the host manipulation hypothesis where the mite behaviour could be altered to favour the transmission of the virus $[93,94]$. More research would help to identify health biomarkers of $V$. destructor that can be influenced by the DWV.

All these key parameters in the understanding of the host/parasite interactions could be as many promising therapeutic targets to control $V$. destructor.

\section{Varroa destructor Chemical and Semi-Chemical Control Methods}

\subsection{Hard Acaricides}

Synthetic acaricides were first used in the 1970s to effectively fight against the acari $[95,96]$. They were easy to use, cheap and effective [5]. Different types were released in the market followed by several research works describing their impact on the mite but also collateral impacts on bees. The formamidine amitraz, pyrethroid tau-fluvalinate and organophosphate coumaphos are the three active ingredients and major hard acaricides used against $V$. destructor. Their mode of action is now well described in the literature. For example, formamidine amitraz holds a toxic effect by interacting with the octopamine receptors involved in insects' nervous system [97]. It inhibits neurotransmission leading to paralysis [98]. As for tau-fluvalinate, it changes kinetics of the voltage-gated sodium channel. 
The axonal membrane permanently depolarised induces the paralysis of the mite [31,99]. In addition, other pyrethroids are known to increase the transcription level of antimicrobial peptides and hymenoptaecin (an antibacterial polypeptide) in bees [100-102] leading to a modified physiology. The last major acaricide, coumaphos, acts as an acetylcholinesterase inhibitor and impedes nerve signalling $[103,104]$.

Due to their modes of action and their impact on gene expression, several works showed that commercial acaricides harm honeybees lethally and sub-lethally. While a few studies do not detect any detrimental effect [105], some have shown olfactory memory impairment [106] or locomotor deficits [28] associated with the presence of acaricide. Another major issue is due to lipophilic properties of these molecules which facilitate their accumulation in bee products especially in wax, thus surexposing honeybees and $V$. destructor to the substance [107-109]. Another drawback to keep in mind is the inability of hard acaricides to reach capped brood, killing the ecto-parasite only out of the reproductive state.

One more exploratory option resides in lithium chloride. Ziegelmann et al. [110] investigated its acaricidal impact by feeding honeybees and analysed their lifespan. This molecule, not yet on the market, showed efficient results against dispersal mites through oral and contact delivery methods [111,112]. However, the question arose about honeybee products potential contamination [113]. Further research is still needed to determine long-term and sub-lethal effects on bees in the laboratory as well as in the field.

The off-target effects, along with the increasing resistances of mites, pushed for new ways of pest control [57] like soft acaricides.

\subsection{Soft Acaricides}

Many molecules from natural origins were considered as alternatives to synthetic chemical treatments. Thymol, formic acid or oxalic acid have been stressed since the 1970s-1980s as efficient treatments against the ecto-parasite [114]. Yet, the 'perfect' solution does not exist, and new molecules are tested each year in the hope to come up with a long-term answer. Some of these molecules have been used for decades without a clear understanding of their mode of actions on both the honeybee and the acari. This is for instance the case of formic acid.

FORMIC ACID-Formic acid holds a great potential since it is the only molecule, so far, able to reach both dispersal and reproductive mites inside brood cells [115]. When used as a treatment, formic acid seems to interfere with the cellular respiratory chain, more precisely the cytochrome $\mathrm{C}$ oxidase. It inhibits the oxidative phosphorylation, thus impacting the mitochondrial energy metabolism [116]. Genath et al., (2020) [117] studied the transcriptome of A. mellifera and V. destructor after topical formic acid treatment and highlighted a difference in detoxification capacity between the host and the acari. Their work supports the hypothesis of interference with cellular respiration through the modified expression of several genes like cytochrome P450 suggesting a stronger toxic selectivity toward the mite. To date, no resistance was detected in $V$. destructor $[59,73]$. Hansen et Guldborg (1988) [118] showed that the formic acid concentration increasing in honey after a treatment was not sufficient to be harmful and persistent in time $[119,120]$. Nevertheless, many parameters such as the delivery methods, the size of the hive, the position of the evaporator in the hive, the humidity and the temperature are known to greatly affect the treatment efficacy [121-124]. For example, high temperature combined with low ventilation in-hive may lead to higher brood toxicity and lower mite mortality due to quick evaporation rates [125]. In addition, several studies described some drawbacks like swarming, queen mortality, damaged young bees or reduction of sealed brood [123,126,127]. At sub-lethal doses, formic acid involved memory impairment for bees in the short and long term [106]. Still, this acid seems a good compromise to keep a reduced number of mites without drastic honeybees loss [123]. In addition to health risk for the user in case of incorrect use, real efficacy is known to variate throughout the world, from $39.8 \%$ of mite mortality in the USA [125] to $92 \%$ in Argentina [128]. 
OXALIC ACID-Oxalic acid is a natural acaricide in use since the 1980s against the mite. Again, this acid is a molecule naturally present in honey [119]. Due to its hydrophilic nature, oxalic acid is used as an acaricide treatment and does not lead to high residual concentration in wax [129-132]. It kills dispersive mites on honeybee body but cannot penetrate a brood cell, limiting its effects [130,133,134]. In field trials, Maggi et al., (2016) for instance, showed a miticide efficacy of $93.1 \%$. Surprisingly its mode of action towards $V$. destructor is still unclear although it is most likely mechanical [73]. Sublimation method seems to cause crystallisation of the acid on the acari's body, leading to the inability of the mite to adhere to any substrate [135]. The fact that $V$. destructor appears unable to detect this acid by olfaction [135] and the putative mechanical mode of action could reduce the chance of resistance from the mite [73]. No resistance was observed over 8 years of treatment in a recent bioassay [32]. Yet, caution should be taken as bacteria characterised from $V$. destructor microbiota were shown to express oxalotrophy. This gives them the ability to degrade oxalic acid in order to use it as their carbon source [136], thus conferring resistances to the carrying mites. Despite its use as an organic treatment, oxalic acid at high and sub-lethal doses can still be harmful to the bees. Severe and irreversible internal tissue damages $[137,138]$ or disruption of the proteolytic activity of the cuticle were observed, impeding bees' immunity [139]. Administration method is actually a key point and higher death rates were associated with oral exposure when compared to topical application [140]. Maggi et al. [32] suggested that the combination of glycerol with oxalic acid may prevent honeybees from oral ingestion, reducing deleterious effects, without reducing the efficacy of the acaricide treatment. Besides the effect on adult bees, experiments led on larval stages with spray application showed midgut damages as well [141]. Finally, tests on long-term effects on colonies characterised loss of brood, workers and sometimes queen according to the concentration used [130,142].

OTHERS - In addition to formic and oxalic acid, several other acids were screened and their effects against $V$. destructor were assessed. While citric and acetic acids were disappointing attempts $[143,144]$, costic and oleic acids sound promising. The extraction of costic acid from Dittichia viscosa plant allowed field tests with a miticide effect of $80 \%$ without apparent bee mortality [145]. More precisely, alpha-costic acid was identified as the compound responsible of the acaricidal activity and was also shown to knock out the mite without killing it [146]. A later work even combined oxalic and costic acids to increase the compound efficiency against $V$. destructor [147]. Despite these promising results, sub-lethal effects on honeybees still need to be precisely explored in vitro and during field trials.

As for oleic acid, it is involved in different biological functions and would constitute a key death pheromone eliciting hygienic behaviour in honeybees [148] and a sexual pheromone for $V$. destructor [72]. Regarding the latest, the authors discovered that a pest management solution through sexual confusion was possible in vitro and on semi-field trials [149]. However, even if oleic acid seems encouraging, it could be a tricky solution to put in use because of its omni-presence and its role in the regulation of diverse behaviours in bee colonies.

Besides acids, essential oils and derivatives were alternatives with good miticide effects [150]. Thymol is commercialised since the 1990s [151]. Derived from thyme oil, it is the most common essential oil-based product used against $V$. destructor. Unfortunately, due to the accumulation in wax, scientists uncovered severe sub-lethal consequences for honeybees [152] like low larvae survival rate, delayed vitellogenin expression [34] or altered specific memory traces [153]. Thymol binds to dopamine receptors, which irritates honeybees and can modify the taste of honey [154,155]. Moreover, it triggers higher hygienic behaviour from bees [156]. Many other essential oils have been tested, and some were even commercialised. For instance, savoury or spearmint oils were investigated and showed acaricidal properties with low rate of honeybee mortality while dillsun induced higher death rates [157]. Menthol in sugar syrup displayed encouraging short-term results [150,158] whereas neem oil killed mites [159], but also increased brood mortality and reduced the worker's walking activity [160]. 
Finally, another plant extract, relying on hop leaves, was shown to contain polyphenols with high miticide effect and low acute toxicity for bees [161,162]. An advantage of hop extracts comes from their antioxidant activity for honeybees, benefiting them if administered orally [33].

\subsection{Years Outcome of Restricted Therapeutic Arsenal: Varroa destructor Biotype Disparities}

Adaptability strikes particularly in the original host of the mite, Apis cerana. Indeed, the long host-parasite coevolution has led to fitness optimality for both through natural selection process. It is well described in the literature that $V$. destructor females reproduce only in drone brood cells in A. cerana hive [163] thus, confining them in a restraint area and timeline. In addition, the Asian bees maintain efficient hygienic behaviour against the mite with infested brood removal, entombing or grooming a nestmate [164-166], thereby maintaining an equilibrium [9]. It is a different story with $A$. mellifera so far where the co-evolution is shorter than $A$. cerana. Nevertheless, several traits such as varroa sensitive hygiene (VSH) or suppressed mite reproduction (SMR) emerged and are still broadly studied [167-169]. In the meantime, chemical solutions were used to face this invader. Hard acaricides were largely described in the literature for causing resistance in the parasite due to long-term exposure to high doses of chemicals. In the colony, the mite population can be divided in three categories: susceptible, tolerant and resistant [170]. Mechanisms of resistance can take several forms such as behavioural acaricide avoidance, desensitisation through changes in the active site, diminished penetration or modulation of detoxification enzyme expression [171]. A majority of acaricides target crucial proteins from the nervous system leading to resistant mites through protein modifications.

In addition, the toxicity efficacy can be challenged by the ecological diversity of mites within colonies (Figure 2). In fact, there are four different states of Varroa females: (1) dispersal ecto-parasite attached to honeybee's body, (2) comb mite freely moving inside the hive, (3) reproductive acari confined in brood cell and (4) non reproductive mite confined in brood cell $[30,172]$. This variety represents distinct targets with their own reachability, which has to be considered while studying molecule toxicity on $V$. destructor. Moreover, the mite population varies from winter to summer and seems adapted to each season. Females are smaller with larger shields and shorter legs in summer. The ratio of morphotypes is dynamic and goes from $20 \%$ of winter morphotype in summer to $20 \%$ of summer morphotype in winter $[173,174]$. Viruses loads add a third dimension where the mite can be free of viruses, positive with replication of the virus or positive without replication of the virus (asymptomatic).

Why extermination is not the solution. Treatments that eradicate susceptible acari keep the least sensitive to reproduce, which leads the $V$. destructor population to become highly resistant over time. It is especially the case with this ecto-parasite because of the high level of inbreeding within colonies. This makes the fixation of resistant alleles happen quicker [48]. To limit this phenomenon, at least temporarily, a rotation in molecular targets should be adopted [175]. Moreover, acaricides used at their lowest effective dose reduce the amount of residues stored in wax or honey, thus moderate the speed in acaricide resistance [176].

As a recent paper by Colin et al., (2020) [177] rightly advocated, acaricides should be tested at sub-lethal level to assess their impact on reproduction, nutrition or even orientation. It is a pity that toxicological studies rely mainly on lethal dose to evaluate the efficiency of the product while eradication of $V$. destructor is not an ecological long-term solution. However, preventing them from reproduction or right orientation, as supported by Soroker et al., (2019) [81], would reduce the selective pressure in favour of the most resistant mites. Other works also explained that the use of natural substances could grant a low level of $V$. destructor infestation, keeping honeybee colonies alive [33]. An integrated pest management strategy should thus, combine all the above ideas. It is necessary to understand the diversity of the $V$. destructor population within one single hive. Long-term alternative methods should rely on safer compounds (e.g., no interference with the nervous 
system) in small quantities altering host preference or mite reproduction through biocontrol and IPM to preserve honeybees.

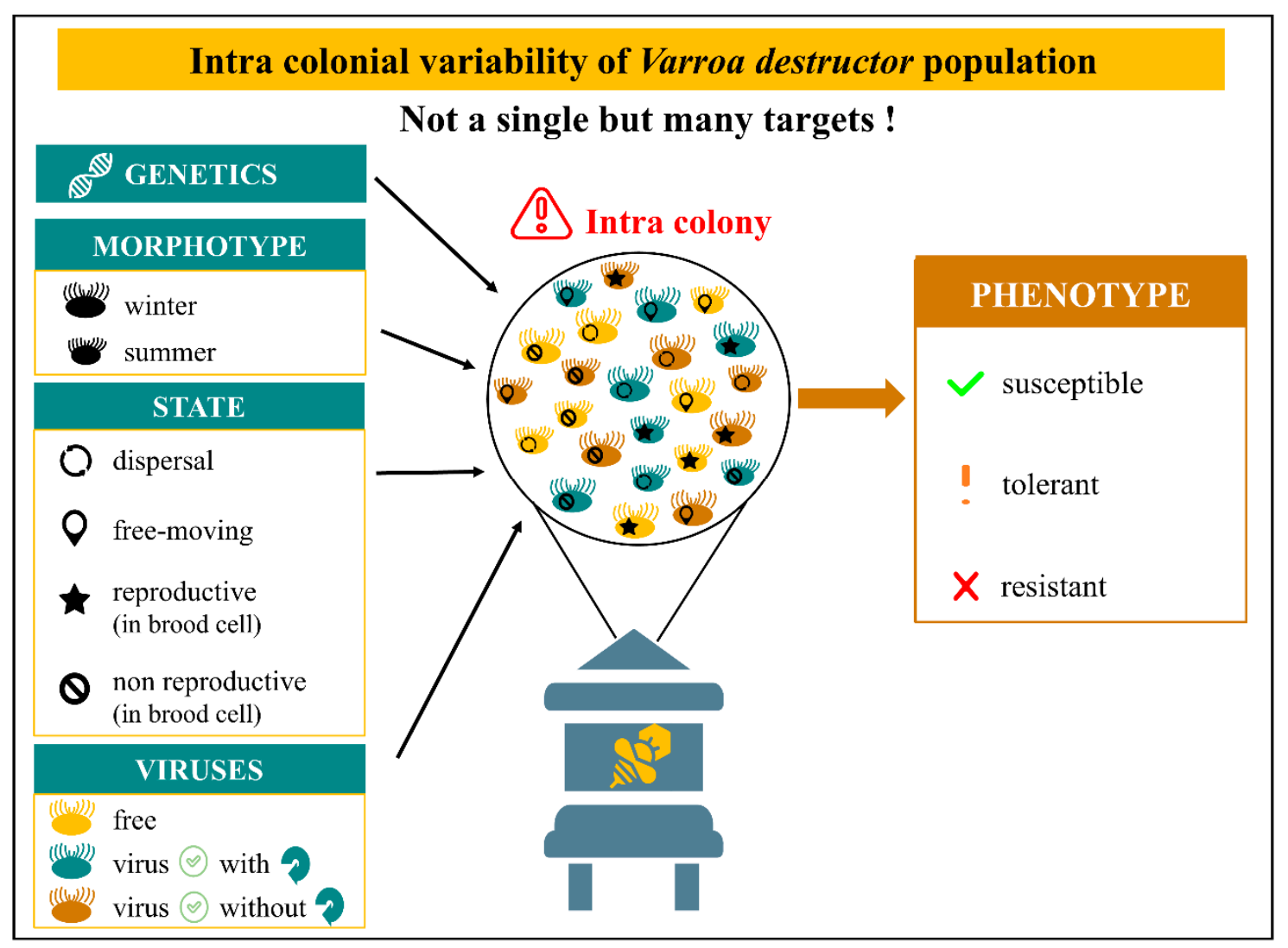

Figure 2. Intra colonial variability of $V$. destructor population. Genetics through several traits can influence the phenotype [168]. Mites differ from winter to summer with a dynamic morphotype ratio going from $20 \%$ of winter morphotype in summer to $20 \%$ of summer morphotype in winter $[173,174]$. In addition, $V$. destructor can be divided in four different states: dispersal ecto-parasite attached to honeybee's body, comb mite freely moving inside the hive, reproductive acari confined in brood cell and non-reproductive mite confined in brood cell [30,172]. Virus loads add a third dimension where the mite can be free of viruses, virus-positive with replication or virus-positive without replication (asymptomatic). This combination of different states, morphotypes and virus loads produce a variety of acari which represents distinct targets with their own reachability.

\section{Biocontrol and IPM Strategies for V. destructor Management}

Here we summarised the main roads of IPM and biocontrol for honeybees against the ecto-parasite explored by scientists.

\subsection{Biotechnical Approach}

Often combined with organic molecules, a mechanical approach can be an alternative as well. The main goal is to perform total brood interruption, removal of drone brood, queen caging or trapping combs to decrease the pressure of $V$. destructor population on the colony $[131,178,179]$. In fact, these mechanical methods allow to artificially create a broodless period where mites have to be on adult honeybees, making them accessible to molecules. The removal of brood frames after a broodless period can also allow the trapping of an important number of reproductive mites. Unfortunately, according to the region of the world, brood interruption does not give the same results. It was the best solution to lower the ecto-parasite pressure on colonies in several countries in Europe but not in the USA where it affected their strength and survival [179-183]. Another method 
called sugar shake, used as a diagnosis method, reduces as well the number of mites on adult honeybees and lower the pressure on the colony without causing deep damages [184].

Regrettably, these techniques are tedious, difficult to execute at large scale and can lead to honey losses which is a problem for beekeepers. Their great advantage is to keep the highest quality and safety standard for honeybee products while reducing $V$. destructor pressure [185].

\subsection{Natural Predators}

Another biological alternative in treatments against $V$. destructor relies on natural predators. Different species were identified as potential candidates.

First, pseudoscorpions can occasionally be observed in hives and feed upon the ectoparasite without harming bees $[186,187]$. They are able to paralyse and kill the mite by injecting their venom from their pincers [188]. Different species were described all over the world like Nesochernes gracilis or Chelifer cancroides. Some seemed beneficial to bees and others not [189]. Recent efforts showed that pseudoscorpions can be mass-reared, making it easier to consider them a long-term solution against $V$. destructor [190]. Yet, a gap in knowledge still needs to be filled regarding their actual utilisation in field experiments.

Second, the predatory mite Stratiolaelaps scimitus is another potential candidate studied for biocontrol solution. Despite an effective ability to kill $V$. destructor, they also prove to prefer the eggs of the honeybee to the mite [191]. Moreover, in field experiments, an introduction in early and late fall did not lead to a decrease in the acari pressure upon colonies [192,193].

It is quite difficult to find the perfect natural predator for $V$. destructor. An efficient mite predator would have to, at least, consume the ecto-parasite eggs or larvae, thus entering a brood cell in tandem with an adult mite [194]. Plus, this organism should not harm the bees, regardless of the stage of development which makes the task truly challenging.

\subsection{Microbiota}

Microbiota is a highly dynamic field of research. For honeybees, worker guts from colonies parasitised with $V$. destructor hold a higher proportion of Snodgrassella alvi and a smaller of Lactobacillus spp., indicating a modification of their microbiota induced by the acari $[195,196]$. Besides, healthy larvae host a large population of Enterobacteriaceae, meanwhile the infested one owns a diversified microbiota similar to the ecto-parasite microbiome [197]. Therefore, the microbiota is a new opportunity to dig in to fight the ecto-parasite. Various strategies have been already experimented by several scientific groups. One of them supports the use of transgenic gut bacteria for biocontrol purposes. A key point to do so, relies on the adaptation of the gut microbiota through transfer of plasmids and trans-conjugation between bacterial strains, making it the best place to transfer genes [198]. Leonard et al. [199] engineered a symbiotic bacterium from honeybees' gut, S. alvi, producing repeatedly dsRNA against essential genes for the acari and were successfully fed to the bees. Ecto-parasites fed from bees nourished with the engineered bacteria died faster than mites fed upon control bees. This elegant research work is a real breakthrough and shows how significant bacteria from honeybees gut could help in the battle against the mite. It also shows that combining several treatment methods (e.g., dsRNAi and microbiota), can be an efficient way of reducing parasite pressure, nicely filling integrative pest management perspectives. Using a different approach based on the study of honeybee's cuticle microbiota, where bacteria already fit the micro-environment of the hive, Sacca et Lodesani [200] also obtained encouraging results. They isolated strains able to induce $V$. destructor's death within 3 days after spraying, namely Lactobacillus kunkeei, Bacillus thuringiensis or Bifidobacterium asteroides.

Rather than targeting the mite, honeybee microbiota can also be used to improve health and resistance in the host. Probiotics were already considered to enhance the immune system against other threats to honeybees like American foulbrood or Nosema ceranae [201-203]. As the acari was spotted to disturb honeybees' gut microbiota (dysbiosis), 
it appeared that probiotics, like Gram-positive bacteria Lactobacillus and Bacillus strains, brought beneficial impacts on colony health and seemed to reduce the incidence of the mite $[195,204,205]$. Bacteria communities appealed as well for their released metabolites. They were tested as treatment against the ecto-parasite. Lactic acid from L. johnsonii AJ5 induced the mite's death when fed to bees. The mechanism implied in $V$. destructor's mortality remains unknown and needs further confirmations [206,207].

\subsection{Pathogens}

Pathogens are another avenue of potential sustainable solutions against the acari. Entomopathogenic bacteria like Bacillus thuringiensis $(\mathrm{Bt})$ are widely used as bioinsecticide agents in crops [208,209]. Bt is a Gram-positive procaryote, naturally present on insects corpses as well as on leaf surface [210]. It penetrates the host via ingestion and produces crystal (protein called Cry) and vegetative toxins. In vitro studies showed that Bt is present on $V$. destructor corpses and were extracted to test their pathogenicity on mites as well as honeybees. They reported that, after being treated with Bt for $24 \mathrm{~h}$, V. destructor trembled, regurgitated, with intestinal inflammation (dysentery) and eventually died [211-213]. Short-term experiment showed no lethal effects among A. mellifera adults or larvae and possibly reduced vertical displacement $[213,214]$ whereas chronic exposure to Bt induced precocious mortality for adults and larvae bees [215]. A lack of field studies does not allow to consider $\mathrm{Bt}$ as a resolutive method against the mite. Moreover, resistance and biosafety are key issues raised by Bt use. The advantage of Bt relies on its fast-action and host specificities which should limit adverse effects on non-targeted organisms [209]. Yet, a watchful care should be taken due to several resistances from lepidoptera and coleoptera species already spotted to transgenic plants which produce Bt proteins [216].

Besides entomopathogenic bacteria, a wide range of studies used entomopathogenic fungi since they kill acarine species $[194,217,218]$. Entomopathogenic fungi spread into their hosts via specialised spores called conidia. It takes 3 to 10 days to destroy the host by a lack of nutrient, water distress, toxins impact and mechanical disruption [219]. In the biocontrol area, Metarhizium anisopliae and Beauveria bassiana are the figurehead with thousands of research papers. The former was studied several times by Kanga et al. [220-223] They explored the effectiveness of the fungi against the mite through dust versus coated strips and determined that broodless periods are more favourable. M. anisopliae seems very persistent due to its presence 42 days after treatment. Field experiments in Texas and Florida showed encouraging results. The efficient formulation seemed tricky but dry conidia sprinkled held good results. Unfortunately, the fungus was also shown to kill honeybees [220,224]. Italian researchers shed light on sub-lethal behavioural impacts of the fungi (M. anisopliae var. anisopliae BIPESCO 5) on the mite that held a repellent effect from nurses carrying conidia [225]. They led as well a field experiment for 24 days which resulted in lower pressure of the acari, although honeybees losses were detected [226]. Besides, $V$. destructor infested-brood inoculated with the fungi showed a recovery in the expression of hymenoptaecin gene, involved in immunity, thus correcting the immunosuppression induced by the mite [227]. To date it is not crystal clear whereas M. anisopliae is safe for honeybees if applied intra hive even considering the improved results showed by Hans et al. [228] with a modified strain. Further experiments are still needed.

Regarding B. bassiana, it seems naturally present in hives, even in brood cells sometimes [229]. Meikle et al. [172,230,231] explored the effect of the fungi on honeybees colonies health while infested by $V$. destructor in field experiments and could not clearly reveal a high efficacy. They investigated the best formulation for an easy use, knowing that conidia germination is a key issue difficult to standardise. If sprayed, it seems to reduce the survival of worker Africanised bees [232].

The main drawback of fungi and bacteria, regardless the lack of data about long-term effects, relies on low specificity of their toxins and complication for them to colonise and survive in the ecosystem of the hive [172,207]. In addition, from a phylogenetic perspective, the honeybee and the ecto-parasite are relatively close, making it harder to reach a single 
one. Conversely, their way of action targets multiple receptors which is supposed to result in a lower and/or slower evolution in host resistance.

\subsection{Double-Stranded RNA Interference (dsRNAi)}

DsRNAi is often mentioned as a recent potential alternative for $V$. destructor pest management $[37,73,81,175]$. In fact, dsRNA induces the degradation of RNA with similar sequences. Therefore, the job of dsRNAi is to momentarily silence targeted gene expression, preventing the protein from filling its function. Varroa destructor holds the molecular machinery to be sensitive to RNAi treatment, administered orally or via dsRNA injection. Campbell et al. [233] showed for the first time that glutathione S-transferase (GST), a key enzyme in the detoxification pathway, could be decreased through dsRNAi injection or submersion of $V$. destructor. A few years later, they also demonstrated that neural peptides could be targeted [94]. Garbian et al. [234] went further and led an elegant experiment demonstrating that dsRNA could be delivered to $V$. destructor by inserting it in honeybees' food. Their work unlocked the delivery issue making it much easier to administer. Besides, odorant receptors as well as genes involved in survival or reproduction were discovered in the mite using RNAi methods $[235,236]$. Odorant receptor knockdown even led to the augmentation of vitellogenin in the acari, simulating the change from non-reproductive to reproductive mode. Although it seems to be a promising method, its long-term and potential risk of mutations or off-target effects are still unclear and largely debated.

\subsection{Chemo-Disruption}

This alternative pest management involves volatiles disturbance associated with key moments in $V$. destructor life cycle $[59,237,238]$. This method requires a full description and understanding of honeybees as well as the mite chemical communication in order to disturb targeted behaviours only. In addition, it is critical to note that many compounds hold different roles and significance according to the diverse hive contexts [59]. Nevertheless, several research attempted to master chemo-disruption, mostly to interfere with the mite's mating behaviour. In vitro and semi-field tests used oleic acid, the sexual pheromone for the mite, but also the hygienic pheromone for honeybees. The aim was to saturate brood cells with the compound to confuse the male and reduce its successful attempts of copulation with suitable females. This technique allowed to reduce by $20 \%$ the number of spermatozoa carried by females [72,149]. Besides sexual confusion, host selection disruption was studied through electrophysiological assay and some compounds like cy $\{2,2\}$ showed efficient results, which pushed the mite to pick a forager instead of a nurse bee, reducing the chance to find a new suitable larvae in brood cells [51]. Several semiochemicals, around 60, were identified over time by researchers that modify the mite behaviour $[60,66,75,81]$ but rarely tested at relevant colony concentration [238]. The tricky part about chemo-disruption in hives is to reach mites inside combs and on honeybees' bodies with an easy application of molecules at a relevant concentration to be effective. This is even more challenging as most of the molecules are also involved in bee pheromonal communication.

Owing to in vitro rearing methods developed lately, a better understanding of molecular pathways, and accurate communication channels used by the ecto-parasite was achieved. It is crucial to put them back into reality through a holistic approach gathering ecological, genetic and physiological factors.

\section{From the Laboratory to the Field: How to Be Realistic?}

Clearly, to identify key factors in host-parasite relationships under laboratory conditions and to be able to transfer these conclusions into the field is a complex and laborious purpose. This is especially the case in studies about eusocial species with a completely different dynamic at the group level [239]. There is no common method to extrapolate laboratory results into the field. Yet, for each case a practical tactic could be examined with an integrative view. Theoretically, a holistic approach through an inverted funnel with a 4-steps loop and feedback could be conducted. This process includes in silico (modelling), 
in vitro rearing and testing, semi-field, field tests and back to modelling with new enriched data (Figure 3). A critical point to set up laboratory experiments is to find a trade-off between being close to natural conditions with complex but relevant conclusions and reducing the natural complexity to try to better interpret parameters of interest. To dig into that direction, accurate technical tools to study the relationship between the parasite and the host including their bacteria or viruses, are capital and sometimes still deficient. For example, the ultimate step for an in vitro rearing method relies on the development of a complete isolation of the ecto-parasite from the host. On the other side of the spectrum, field studies could benefit from easy to use technical tools to track honeybees on long distances [240]. Besides these technical issues and on a more applied research aspect many in vitro applications were often led but hardly pushed through the long run until a successful field product was released.

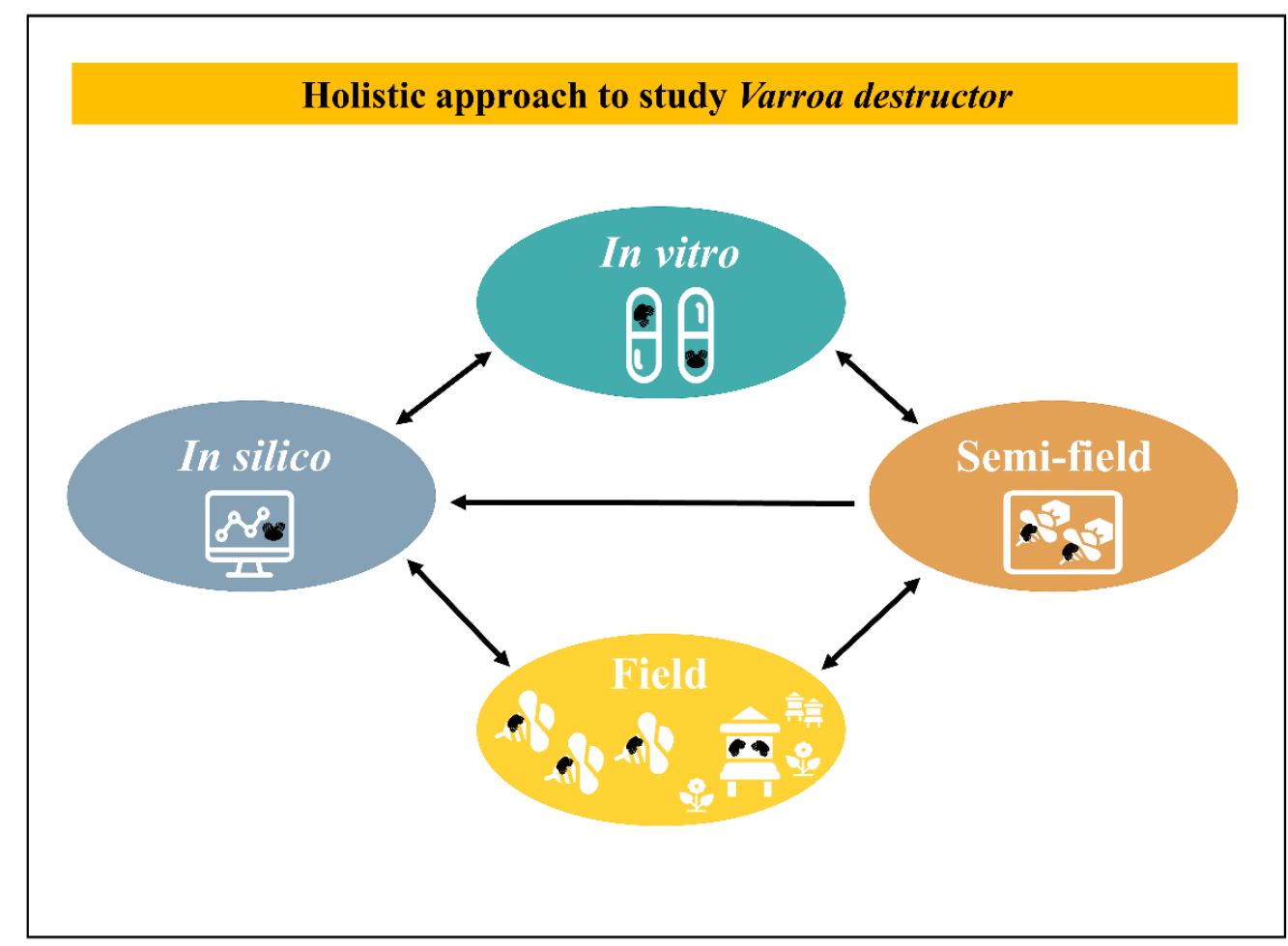

Figure 3. Holistic approach to study V. destructor. This process includes in silico, in vitro, semi-field, field tests and back to modelling with new enriched data. Each arrow indicates enriched exchanges between scales.

\subsection{In Vitro Methods}

To identify key elements in the physiology and biology of the mite with precise reproducibility, obtaining a large quantity of $V$. destructor is crucial. This is quite a challenge as relying on colonies implies high risks of colony losses and seasonal constraints [241]. In vitro rearing is thus, a promising tool for obtaining such a large number of mites while being able to study the parasite cycle in detail. The first main technical lock to study $V$. destructor is supported by its incapacity to survive or complete its cycle detached from its host and out of a brood cell, making an entirely controlled study complicated in the laboratory. That is why available in vitro rearing methods to study the reproductive acari are still dependent on the presence of bee larvae [183,242]. A full in vitro rearing with alive and reproductive daughters maintained out of the season is, to our knowledge, not available yet. Some current methods for instance use freshly collected larvae transferred into gelatine capsules, in which a foundress is inserted to obtain viable offspring after 12 days [243-245]. Maintenance of living $V$. destructor on synthetic feeding membranes is 
possible too. Parafilm or chitosan surfaces were created to study the nutrition, reproduction or virus infection of mites [25,36,246-249]. In these conditions, survival was possible for a few days and the initiation of reproduction was sometimes observed. In laboratory conditions, more than 20 molecules naturally emitted in bee colonies were identified but only a few were tested in field. For example, in natural conditions, after application of methyl palmitate to brood cells, Boot [250] did not observe any attractive effect like previously demonstrated in controlled environment [251]. This point shows how tricky it can be to transfer in vitro results into the field.

While essential, those laboratory results still lack the countless sonar, tactile or olfactory cues naturally present within a hive. Semi field and field studies, on the other hand, allow the inclusion of such parameters to further understand the parasite cycle.

\subsection{Semi Field and Field Scales}

SEMI-FIELD—An intermediate step between in hive and in vitro studies consists of semi-field experiments, for example by using beehive frames brought into the laboratory. Indeed, while being out of the full complex environment of the hive, it allows the inclusion of important sources of interactions, such as those emitted by the brood, the wax or the food. By considering part of this complex environment, Light et al. [252] showed that many of the $V$. destructor volatile attractants isolated in laboratory studies were not detected when a whole frame was analysed. Furthermore, in the case of chemo-disruption, if many kairomonal candidates have been identified [81], attempts of delivering these distracting odours in an accurate range in natural or semi natural conditions are scarce. To our knowledge, this crucial step from the laboratory to the field was only successfully achieved once in the case of sexual pheromone confusion [72]. One of the reasons for this void lies in the fact that establishing protocols to disturb the mite cycle without impacting honeybee communication is a critical task.

FIELD—For eusocial species, like A. mellifera, studies at the colony level remain crucial. Unfortunately, in the darkness of the hive, to collect quantitative data on a wide range of individuals for long periods can be tricky. One of the solutions rely on connected hives [253]. It should allow us to measure some variables like temperature, hygrometry, vibrations but as well social exchanges for bees and why not mite movements. Some exciting new works caught inside videos of within comb cell exploring the movements of honeybees from egg to emergence as well as feeding behaviour from nurses to larvae [254,255]. This type of tracking is essential to reconnect laboratory observations to field experiments. The recent development and adaptation of gas sensor systems to beekeeping practices is really promising. They have already been used to infer a parasite pressure based on volatils detected in hives $[256,257]$. It is necessary to be able to precisely assess the state of the colony when infested with the acari, thus to use acaricides only if required and at the right moment $[175,257]$. From an IPM perspective and regardless of the agent, the formulation is also crucial. The active ingredient needs to survive in the environment of the hive and to access its target without or with the minimum off-target effects. The formulation of a biocontrol agent should thus depend on the environment where it is delivered. In the same way, the heterogeneity of the $V$. destructor population intra hive, between hives and locations has to be taken into account. The numerous sources of physiological, pathological, environmental, behavioural and genetic variations can interfere with the treatment against the mite and determine the success of the method (Figure 2) [172,174,258]. Several works took this aspect into account while testing different molecules or agents against the acari and showed a customised response per location [29,222,259]. To improve our knowledge about the host-parasite dynamic, we still need further research including these aspects to get the full picture from the molecular scale to the population dynamic [260].

\subsection{In Silico (Modelling Approach)}

Modelling approach is part of an integrative strategy to identify key elements in the host-parasite relationship using a high number of colonies. This powerful tool helps to 
represent complex systems, to test multi-factor hypotheses, to predict the outcome of hostpathogen interactions without the cost of individuals, time or money and to estimate crucial parameters from data [261-263]. Moreover, the use of models allows scientists to handle simulated experiments when conducting those experiments is realistically impossible. It is, thus a powerful tool to explore and understand the complexities of ecosystems [264], especially when associated with field data [265]. In the case of host-parasite dynamics, it is well-known that they are influenced by the exchange between parasite and host density. This phenomenon is illustrated through the central transmission-density function. Here the difficulty relies on the selection of the best model, the more representative of the reality [266]. However, it highlights crucial variables involved in the issue. For example, in the triangle $A$. mellifera, $V$. destructor and viruses like DWV or APV (acute paralysis virus) vectored by the mite, the modelling approach showed a similar population dynamic as the one measured in the field. It demonstrated that DWV reduces the number of healthy young bees accessing the overwintering population. This imbalanced situation in ages for the colony results in losses during winter or spring. Unfortunately, around $2000 \mathrm{~V}$. destructor females in autumn seems enough to lead to death. The model predicted a widely spread DWV due to its lower virulence compared to another virus. They indicated as well that prior to the generation of overwintering honeybees, the ecto-parasite pressure should be reduced [267-269]. An interesting point with the latest development in modelling approach remains in the study of sub-lethal doses of pesticides and their combined effect on the colonies [270] as well as the long-term effect of antibiotics on bees [271]. Even acute contact toxicity was predicted recently [272], advocating for a deeper connection between in silico, in vitro, semi-field and field experiments. In the end, the host-parasite relationship should be part of an integrative view and inserted in a wider picture where other variables like poor nutrition, crop pesticides or pathogens are assessed to identify if they act in synergism or antagonism inside the hive [273].

\section{Conclusions}

In the absence of a better solution, the current optimal strategy seems to be the use of oxalic acid in glycerol strips combined to biotechnical approach [32,179,181]. A tight monitoring of the infestation level is a key element to be effective. Rotation in time and space for treatments among hives can help to reduce the resistance spill over $[48,274]$. However, according to climate and country legislation the achievement and results can be dramatically different.

More than ever, researchers need to develop control strategies against $V$. destructor that adopt effective alternatives to hard chemicals, well-known to generate problems like residuals and resistance. If the use of organic acids, plant products and biological control were investigated these last years, none is conclusive for $V$. destructor management yet. The stumble point resides in the transfer of results obtained in the laboratory conditions to the field. In such a context, it would be necessary to intensify attempts, which rely on gene expression datasets, to discover a robust and reliable panel of health biomarkers towards integrated control of $V$. destructor. In the end, a holistic approach, evaluating at sublethal level different biotic and abiotic factors, will be a relevant pest management tool for sustainable apicultural and agricultural production while getting closer to field conditions.

Author Contributions: Writing—original draft preparation, C.V.; writing-review and editing, C.V., V.P., F.V. and A.V.; supervision, A.V.; funding acquisition, F.V. and A.V. All authors have read and agreed to the published version of the manuscript.

Funding: Caroline Vilarem is funded by a grant from M2i Biocontrol and Vincent Piou by a grant from the Région Occitanie (ADEME grant $n^{\circ} 2082 C 0061$ ).

Conflicts of Interest: The authors declare that they have no potential conflict of interest in relation to the review. 


\section{References}

1. Henry, M.; Beguin, M.; Requier, F.; Rollin, O.; Odoux, J.-F.; Aupinel, P.; Aptel, J.; Tchamitchian, S.; Decourtye, A. A Common Pesticide Decreases Foraging Success and Survival in Honey Bees. Science 2012, 336, 348-350. [CrossRef]

2. Le Conte, Y.; Navajas, M. Climate Change: Impact on Honey Bee Populations and Diseases. Rev. Sci. Tech. 2008, 27, 485-497, 499-510. [CrossRef] [PubMed]

3. Brown, M.J.F.; Paxton, R.J. The Conservation of Bees: A Global Perspective. Apidologie 2009, 40, 410-416. [CrossRef]

4. Gómez-Moracho, T.; Heeb, P.; Lihoreau, M. Effects of Parasites and Pathogens on Bee Cognition: Bee Parasites, Pathogens and Cognition. Ecol. Entomol. 2017, 42, 51-64. [CrossRef]

5. Rosenkranz, P.; Aumeier, P.; Ziegelmann, B. Biology and Control of Varroa destructor. J. Invertebr. Pathol. 2010, 103, S96-S119. [CrossRef] [PubMed]

6. Smith, K.M.; Loh, E.H.; Rostal, M.K.; Zambrana-Torrelio, C.M.; Mendiola, L.; Daszak, P. Pathogens, Pests, and Economics: Drivers of Honey Bee Colony Declines and Losses. EcoHealth 2013, 10, 434-445. [CrossRef]

7. Seeley, T.D. The Lives of Bees: The Untold Story of the Honey Bee in the Wild; Princeton University Press: Princeton, NJ, USA, 2019; ISBN 978-0-691-18938-3.

8. Oldroyd, B.P. Coevolution While You Wait: Varroa jacobsoni, a New Parasite of Western Honey bees. Trends Ecol. Evol. 1999, 14, 312-315. [CrossRef]

9. Rath, W.; Drescher, W. Response of Apis cerana fabr towards Brood Infested with Varroa jacobsoni oud and Infestation Rate of Colonies in Thailand. Apidologie 1990, 21, 311-321. [CrossRef]

10. Fries, I.; Huazhen, W.; Wei, S.; Jin, C.S. Grooming Behavior and Damaged Mites (Varroa jacobsoni) in Apis cerana cerana and Apis mellifera ligustica. Apidologie 1996, 27, 3-11. [CrossRef]

11. Wang, S.; Lin, Z.; Chen, G.; Page, P.; Hu, F.; Niu, Q.; Su, X.; Chantawannakul, P.; Neumann, P.; Zheng, H.; et al. Reproduction of Ectoparasitic Mites in a Coevolved System: Varroa Spp.-Eastern Honey Bees, Apis cerana. Ecol. Evol. 2020, ece3.7038. [CrossRef]

12. Ongus, J.R.; Peters, D.; Bonmatin, J.-M.; Bengsch, E.; Vlak, J.M.; van Oers, M.M. Complete Sequence of a Picorna-like Virus of the Genus Iflavirus Replicating in the Mite Varroa destructor. J. Gen. Virol. 2004, 85, 3747-3755. [CrossRef]

13. Lanzi, G.; de Miranda, J.R.; Boniotti, M.B.; Cameron, C.E.; Lavazza, A.; Capucci, L.; Camazine, S.M.; Rossi, C. Molecular and Biological Characterization of Deformed Wing Virus of Honey bees (Apis mellifera L.). J. Virol. 2006, 80, 4998-5009. [CrossRef]

14. Mordecai, G.J.; Wilfert, L.; Martin, S.J.; Jones, I.M.; Schroeder, D.C. Diversity in a Honey Bee Pathogen: First Report of a Third Master Variant of the Deformed Wing Virus Quasispecies. ISME J. 2016, 10, 1264-1273. [CrossRef] [PubMed]

15. Dainat, B.; Neumann, P. Clinical Signs of Deformed Wing Virus Infection Are Predictive Markers for Honey Bee Colony Losses. J. Invertebr. Pathol. 2013, 112, 278-280. [CrossRef] [PubMed]

16. Roberts, J.M.K.; Anderson, D.L.; Durr, P.A. Absence of Deformed Wing Virus and Varroa destructor in Australia Provides Unique Perspectives on Honey bee Viral Landscapes and Colony Losses. Sci. Rep. 2017, 7, 6925. [CrossRef] [PubMed]

17. Gisder, S.; Aumeier, P.; Genersch, E. Deformed Wing Virus: Replication and Viral Load in Mites (Varroa destructor). J. Gen. Virol. 2009, 90, 463-467. [CrossRef]

18. Dainat, B.; Evans, J.D.; Chen, Y.P.; Gauthier, L.; Neumann, P. Dead or Alive: Deformed Wing Virus and Varroa destructor Reduce the Life Span of Winter Honey bees. Appl. Environ. Microbiol. 2012, 78, 981-987. [CrossRef]

19. Iqbal, J.; Mueller, U. Virus Infection Causes Specific Learning Deficits in Honey bee Foragers. Proc. R Soc. B 2007, $274,1517-1521$. [CrossRef]

20. Zanni, V.; Değirmenci, L.; Annoscia, D.; Scheiner, R.; Nazzi, F. The Reduced Brood Nursing by Mite-Infested Honey Bees Depends on Their Accelerated Behavioral Maturation. J. Insect Physiol. 2018, 109, 47-54. [CrossRef]

21. Santillán-Galicia, M.T.; Carzaniga, R.; Ball, B.V.; Alderson, P.G. Immunolocalization of Deformed Wing Virus Particles within the Mite Varroa destructor. J. Gen. Virol. 2008, 89, 1685-1689. [CrossRef]

22. Zhang, Y.; Han, R. A Saliva Protein of Varroa Mites Contributes to the Toxicity toward Apis cerana and the DWV Elevation in $A$. mellifera. Sci. Rep. 2018, 8, 3387. [CrossRef]

23. Posada-Florez, F.; Childers, A.K.; Heerman, M.C.; Egekwu, N.I.; Cook, S.C.; Chen, Y.; Evans, J.D.; Ryabov, E.V. Deformed Wing Virus Type A, a Major Honey Bee Pathogen, Is Vectored by the Mite Varroa destructor in a Non-Propagative Manner. Sci. Rep. 2019, 9, 12445. [CrossRef] [PubMed]

24. Gisder, S.; Genersch, E. Direct Evidence for Infection of Varroa destructor Mites with the Bee-Pathogenic Deformed Wing Virus Variant B-But Not Variant A-Via Fluorescence- in Situ -Hybridization Analysis. J. Virol. 2020, 95, 5. [CrossRef]

25. Gusachenko, O.N.; Woodford, L.; Balbirnie-Cumming, K.; Campbell, E.M.; Christie, C.R.; Bowman, A.S.; Evans, D.J. Green Bees: Reverse Genetic Analysis of Deformed Wing Virus Transmission, Replication, and Tropism. Viruses 2020, 12, 532. [CrossRef]

26. Yañez, O.; Piot, N.; Dalmon, A.; de Miranda, J.R.; Chantawannakul, P.; Panziera, D.; Amiri, E.; Smagghe, G.; Schroeder, D.; Chejanovsky, N. Bee Viruses: Routes of Infection in Hymenoptera. Front. Microbiol. 2020, 11, 943. [CrossRef]

27. Potts, S.G.; Biesmeijer, J.C.; Kremen, C.; Neumann, P.; Schweiger, O.; Kunin, W.E. Global Pollinator Declines: Trends, Impacts and Drivers. Trends Ecol. Evol. 2010, 25, 345-353. [CrossRef] [PubMed]

28. Charreton, M.; Decourtye, A.; Henry, M.; Rodet, G.; Sandoz, J.-C.; Charnet, P.; Collet, C. A Locomotor Deficit Induced by Sublethal Doses of Pyrethroid and Neonicotinoid Insecticides in the Honey bee Apis mellifera. PLoS ONE 2015, 10, e0144879. [CrossRef]

29. Higes, M.; Martín-Hernández, R.; Hernández-Rodríguez, C.S.; González-Cabrera, J. Assessing the Resistance to Acaricides in Varroa destructor from Several Spanish Locations. Parasitol. Res. 2020, 119, 3595-3601. [CrossRef] 
30. Eynard, S.E.; Sann, C.; Basso, B.; Guirao, A.-L.; Le Conte, Y.; Servin, B.; Tison, L.; Vignal, A.; Mondet, F. Descriptive Analysis of the Varroa Non-Reproduction Trait in Honey Bee Colonies and Association with Other Traits Related to Varroa Resistance. Insects 2020, 11, 492. [CrossRef]

31. Wieczorek, P.; Frąckowiak, P.; Obrępalska-Stęplowska, A. Evaluation of the Expression Stability of Reference Genes in Apis mellifera under Pyrethroid Treatment. Sci. Rep. 2020, 10, 16140. [CrossRef]

32. Maggi, M.; Tourn, E.; Negri, P.; Szawarski, N.; Marconi, A.; Gallez, L.; Medici, S.; Ruffinengo, S.; Brasesco, C.; De Feudis, L.; et al. A New Formulation of Oxalic Acid for Varroa destructor Control Applied in Apis mellifera Colonies in the Presence of Brood. Apidologie 2016, 47, 596-605. [CrossRef]

33. Iglesias, A.; Gimenez Martinez, P.; Ramirez, C.; Mitton, G.; Meroi Arcerito, F.R.; Fangio, M.F.; Churio, M.S.; Fuselli, S.; Fanovich, A.; Eguaras, M.; et al. Valorization of Hop Leaves for Development of Eco-Friendly Bee Pesticides. Apidologie 2020, 52, 186-198. [CrossRef]

34. Charpentier, G.; Vidau, C.; Ferdy, J.-B.; Tabart, J.; Vetillard, A. Lethal and Sub-Lethal Effects of Thymol on Honey bee (Apis mellifera) Larvae Reared in Vitro: Toxicity of Thymol on Honey bee Larvae Reared in Vitro. Pest. Manag. Sci. 2014, 70, 140-147. [CrossRef] [PubMed]

35. Colin, T.; Plath, J.A.; Klein, S.; Vine, P.; Devaud, J.-M.; Lihoreau, M.; Meikle, W.G.; Barron, A.B. The Miticide Thymol in Combination with Trace Levels of the Neonicotinoid Imidacloprid Reduces Visual Learning Performance in Honey Bees (Apis mellifera). Apidologie 2020, 51, 499-509. [CrossRef]

36. Ramsey, S.D.; Ochoa, R.; Bauchan, G.; Gulbronson, C.; Mowery, J.D.; Cohen, A.; Lim, D.; Joklik, J.; Cicero, J.M.; Ellis, J.D.; et al. Varroa destructor Feeds Primarily on Honey Bee Fat Body Tissue and Not Hemolymph. Proc. Natl. Acad. Sci. USA 2019, 116, 1792-1801. [CrossRef] [PubMed]

37. Traynor, K.S.; Mondet, F.; de Miranda, J.R.; Techer, M.; Kowallik, V.; Oddie, M.A.Y.; Chantawannakul, P.; McAfee, A. Varroa destructor: A Complex Parasite, Crippling Honey Bees Worldwide. Trends Parasitol. 2020, 36, 592-606. [CrossRef]

38. Häußermann, C.K.; Ziegelmann, B.; Rosenkranz, P. Spermatozoa Capacitation in Female Varroa destructor and Its Influence on the Timing and Success of Female Reproduction. Exp. Appl. Acarol. 2016, 69, 371-387. [CrossRef]

39. Boot, W.J.; Calis, J.N.M.; Beetsma, J. Invasion of Varroa jacobsons into Honey Bee Brood Cells: A Matter of Chance or Choice? J. Apic. Res. 1993, 32, 167-174. [CrossRef]

40. Rosenkranz, P.; Garrido, C. Volatiles of the Honey Bee Larva Initiate Oogenesis in the Parasitic Mite Varroa destructor. Evol. Mech. Environ. Approaches Chem.-Mediat. Interact. 2004, 14, 193-197. [CrossRef]

41. Martin, S.J. Ontogenesis of the Mite Varroa Jacobsoni Oud. in Worker Brood of the Honey bee Apis mellifera L. under Natural Conditions. Exp. Appl. Acarol. 1994, 18, 87-100. [CrossRef]

42. Kanbar, G.; Engels, W. Ultrastructure and Bacterial Infection of Wounds in Honey Bee (Apis mellifera) Pupae Punctured by Varroa Mites. Parasitol. Res. 2003, 90, 349-354. [CrossRef]

43. De Lillo, E.; Di Palma, A.; Nuzzaci, G. Morphological Adaptations of Mite Chelicerae to Different Trophic Activities (Acari). Entomologica 2016, 35, 125-180. [CrossRef]

44. Richards, E.H.; Jones, B.; Bowman, A. Salivary Secretions from the Honey bee Mite, Varroa destructor: Effects on Insect Haemocytes and Preliminary Biochemical Characterization. Parasitology 2011, 138, 602-608. [CrossRef] [PubMed]

45. Becchimanzi, A.; Tatè, R.; Campbell, E.M.; Gigliotti, S.; Bowman, A.S.; Pennacchio, F. A Salivary Chitinase of Varroa destructor Influences Host Immunity and Mite's Survival. PLoS Pathog. 2020, 16, e1009075. [CrossRef] [PubMed]

46. Rehm, S.-M.; Ritter, W. Sequence of the Sexes in the Offspring of Varroa jacobsoni and the Resulting Consequences for the Calculation of the Developmental Period. Apidologie 1989, 20, 339-343. [CrossRef]

47. Donzé, G.; Herrmann, M.; Bachofen, B.; Guerin, P.R.M. Effect of Mating Frequency and Brood Cell Infestation Rate on the Reproductive Success of the Honey bee Parasite Varroa jacobsoni. Ecol. Entomol. 1996, 21, 17-26. [CrossRef]

48. Beaurepaire, A.L.; Krieger, K.J.; Moritz, R.F.A. Seasonal Cycle of Inbreeding and Recombination of the Parasitic Mite Varroa destructor in Honey bee Colonies and Its Implications for the Selection of Acaricide Resistance. Infect. Genet. Evol. 2017, 50, 49-54. [CrossRef]

49. de Ruijter, A. Reproduction of Varroa jacobsoni during Successive Brood Cycles of the Honey bee. Apidologie 1987, 18, 321-326. [CrossRef]

50. Häußermann, C.K.; Giacobino, A.; Munz, R.; Ziegelmann, B.; Palacio, M.A.; Rosenkranz, P. Reproductive Parameters of Female Varroa destructor and the Impact of Mating in Worker Brood of Apis mellifera. Apidologie 2020, 51, 342-355. [CrossRef]

51. Eliash, N.; Singh, N.K.; Kamer, Y.; Pinnelli, G.R.; Plettner, E.; Soroker, V. Can We Disrupt the Sensing of Honey Bees by the Bee Parasite Varroa destructor? PLoS ONE 2014, 9, e106889. [CrossRef]

52. Sakai, A.K.; Allendorf, F.W.; Holt, J.S.; Lodge, D.M.; Molofsky, J.; With, K.A.; Baughman, S.; Cabin, R.J.; Cohen, J.E.; Ellstrand, N.C.; et al. The Population Biology of Invasive Species. Annu. Rev. Ecol. Syst. 2001, 32, 305-332. [CrossRef]

53. Moro, A.; Blacquière, T.; Dahle, B.; Dietemann, V.; Le Conte, Y.; Locke, B.; Neumann, P.; Beaurepaire, A. Adaptive Population Structure Shifts in Invasive Parasitic Mites, Varroa destructor. Ecol. Evol. 2021, 11, 5937-5949. [CrossRef] [PubMed]

54. Dynes, T.L.; De Roode, J.C.; Lyons, J.I.; Berry, J.A.; Delaplane, K.S.; Brosi, B.J. Fine Scale Population Genetic Structure of Varroa destructor, an Ectoparasitic Mite of the Honey Bee (Apis mellifera). Apidologie 2017, 48, 93-101. [CrossRef] [PubMed]

55. Frey, E.; Rosenkranz, P. Autumn Invasion Rates of Varroa destructor (Mesostigmata: Varroidae) Into Honey Bee (Hymenoptera: Apidae) Colonies and the Resulting Increase in Mite Populations. J. Econ. Entomol. 2014, 107, 508-515. [CrossRef] [PubMed] 
56. Peck, D.T.; Seeley, T.D. Mite Bombs or Robber Lures? The Roles of Drifting and Robbing in Varroa destructor Transmission from Collapsing Honey Bee Colonies to Their Neighbors. PLoS ONE 2019, 14, e0218392. [CrossRef]

57. Roush, R.T.; McKenzie, J.A. Ecological Genetics of Insecticide and Acaricide Resistance. Annu. Rev. Entomol. 1987, 32, 361-380. [CrossRef] [PubMed]

58. Bortolotti, L.; Costa, C. Chemical Communication in the Honey Bee Society. In Neurobiology of Chemical Communication; MucignatCaretta, C., Ed.; Frontiers in Neuroscience; CRC Press/Taylor \& Francis: Boca Raton, FL, USA, 2014; ISBN 978-1-4665-5341-5.

59. Plettner, E.; Eliash, N.; Singh, N.K.; Pinnelli, G.R.; Soroker, V. The Chemical Ecology of Host-Parasite Interaction as a Target of Varroa destructor Control Agents. Apidologie 2017, 48, 78-92. [CrossRef]

60. Le Conte, Y.; Arnold, G.; Trouiller, J.; Masson, C.; Chappe, B.; Ourisson, G. Attraction of the Parasitic Mite Varroa to the Drone Larvae of Honey Bees by Simple Aliphatic Esters. Science 1989, 245, 638-639. [CrossRef]

61. Calderone, N.W.; Lin, S. Behavioural Responses of Varroa destructor (Acari: Varroidae) to Extracts of Larvae, Cocoons and Brood Food of Worker and Drone Honey Bees, Apis mellifera (Hymenoptera: Apidae): Responses of $V$. destructor to Host Kairomones. Physiol. Entomol. 2001, 26, 341-350. [CrossRef]

62. Donzé, G.; Schnyder-Candrian, S.; Bogdanov, S.; Diehl, P.-A.; Guerin, P.M.; Kilchenman, V.; Monachon, F. Aliphatic Alcohols and Aldehydes of the Honey Bee Cocoon Induce Arrestment Behavior in Varroa jacobsoni (Acari: Mesostigmata), an Ectoparasite of Apis mellifera. Insect Biochem. Physiol. 1998, 37, 129-145. [CrossRef]

63. Nazzi, F.; Della Vedova, G.; D’Agaro, M. A Semiochemical from Brood Cells Infested by Varroa destructor Triggers Hygienic Behaviour in Apis mellifera. Apidologie 2004, 35, 65-70. [CrossRef]

64. Drijfhout, F.P.; Kochansky, J.; Lin, S.; Calderone, N.W. Components of Honey bee Royal Jelly as Deterrents of the Parasitic Varroa Mite, Varroa destructor. J. Chem. Ecol. 2005, 31, 1747-1764. [CrossRef]

65. Trouiller, J.; Arnold, G.; Chappe, B.; Le Conte, Y.; Billion, A.; Masson, C. The Kairomonal Esters Attractive to the Varroa jacobsoni Mite in the Queen Brood. Apidologie 1994, 25, 314-321. [CrossRef]

66. Pernal, S.F.; Baird, D.S.; Birmingham, A.L.; Higo, H.A.; Slessor, K.N.; Winston, M.L. Semiochemicals Influencing the Host-Finding Behaviour of Varroa destructor. Exp. Appl. Acarol. 2005, 37, 1-26. [CrossRef]

67. Piccolo, F.D.; Nazzi, F.; Vedova, G.D.; Milani, N. Selection of Apis mellifera Workers by the Parasitic Mite Varroa destructor Using Host Cuticular Hydrocarbons. Parasitology 2010, 137, 967-973. [CrossRef]

68. Kuenen, L.P.S.; Calderone, N.W. Transfers of Varroa Mites from Newly Emerged Bees: Preferences for Age- and Function-Specific Adult Bees (Hymenoptera: Apidae). J. Insect. Behav. 1997, 10, 213-228. [CrossRef]

69. Xie, X.; Huang, Z.Y.; Zeng, Z. Why Do Varroa Mites Prefer Nurse Bees? Sci. Rep. 2016, 6, 28228. [CrossRef] [PubMed]

70. Nazzi, F.; Le Conte, Y. Ecology of Varroa destructor, the Major Ectoparasite of the Western Honey Bee, Apis mellifera. Annu. Rev. Entomol. 2016, 61, 417-432. [CrossRef] [PubMed]

71. Nganso, B.T.; Mani, K.; Altman, Y.; Rafaeli, A.; Soroker, V. How Crucial Is the Functional Pit Organ for the Varroa Mite? Insects 2020, 11, 395. [CrossRef] [PubMed]

72. Ziegelmann, B.; Lindenmayer, A.; Steidle, J.; Rosenkranz, P. The Mating Behavior of Varroa destructor Is Triggered by a Female Sex Pheromone: Part 1: Preference Behavior of Male Mites in a Laboratory Bioassay. Apidologie 2013, 44, 314-323. [CrossRef]

73. Evans, J.D.; Cook, S.C. Genetics and Physiology of Varroa Mites. Curr. Opin. Insect Sci. 2018, 26, 130-135. [CrossRef]

74. Cabrera Cordon, A.R.; Shirk, P.D.; Duehl, A.J.; Evans, J.D.; Teal, P.E.A. Variable Induction of Vitellogenin Genes in the Varroa Mite, Varroa destructor (Anderson \& Trueman), by the Honey bee, Apis mellifera L, Host and Its Environment: Varroa Mite Vitellogenin Gene Regulation. Insect Mol. Biol. 2013, 22, 88-103. [CrossRef]

75. Frey, E.; Odemer, R.; Blum, T.; Rosenkranz, P. Activation and Interruption of the Reproduction of Varroa destructor Is Triggered by Host Signals (Apis mellifera). J. Invertebr. Pathol. 2013, 113, 56-62. [CrossRef]

76. Garrido, C.; Rosenkranz, P. The Reproductive Program of Female Varroa destructor Mites Is Triggered by Its Host, Apis mellifera. Exp. Appl. Acarol. 2003, 31, 269-273. [CrossRef]

77. Le Conte, Y.; Huang, Z.Y.; Roux, M.; Zeng, Z.J.; Christidès, J.-P.; Bagnères, A.-G. Varroa destructor Changes Its Cuticular Hydrocarbons to Mimic New Hosts. Biol. Lett. 2015, 11, 20150233. [CrossRef] [PubMed]

78. Nation, J.L.; Sanford, M.T.; Milne, K. Cuticular Hydrocarbons from Varroa jacobsoni. Exp. Appl. Acarol. 1992, 16, 331-344. [CrossRef]

79. Kather, R.; Drijfhout, F.P.; Shemilt, S.; Martin, S.J. Evidence for Passive Chemical Camouflage in the Parasitic Mite Varroa destructor. J. Chem. Ecol. 2015, 41, 178-186. [CrossRef] [PubMed]

80. Keeling, C.I.; Plettner, E.; Slessor, K.N. Hymenopteran Semiochemicals. In The Chemistry of Pheromones and Other Semiochemicals I.; Schulz, S., Ed.; Topics in Current Chemistry; Springer: Berlin/Heidelberg, Germany, 2004; Volume 239, pp. 133-177, ISBN 978-3-540-20828-0.

81. Soroker, V.; Singh, N.K.; Eliash, N.; Plettner, E. Olfaction as a Target for Control of Honey bee Parasite Mite Varroa destructor. In Olfactory Concepts of Insect Control-Alternative to Insecticides; Picimbon, J.-F., Ed.; Springer International Publishing: Cham, Switzerland, 2019; pp. 117-134, ISBN 978-3-030-05059-7.

82. Kraus, B. Factors Influencing Host Choice of the Honey Bee Parasite Varroa jacobsoni Oud. Exp. Appl. Acarol. 1994, 18, 435-443. [CrossRef]

83. Cervo, R.; Bruschini, C.; Cappa, F.; Meconcelli, S.; Pieraccini, G.; Pradella, D.; Turillazzi, S. High Varroa Mite Abundance Influences Chemical Profiles of Worker Bees and Mite-Host Preferences. J. Exp. Biol. 2014, 217, 2998-3001. [CrossRef] 
84. Highfield, A.C.; El Nagar, A.; Mackinder, L.C.M.; Noël, L.M.-L.J.; Hall, M.J.; Martin, S.J.; Schroeder, D.C. Deformed Wing Virus Implicated in Overwintering Honey bee Colony Losses. Appl. Environ. Microbiol. 2009, 75, 7212-7220. [CrossRef] [PubMed]

85. Wilfert, L.; Long, G.; Leggett, H.C.; Schmid-Hempel, P.; Butlin, R.; Martin, S.J.M.; Boots, M. Deformed Wing Virus Is a Recent Global Epidemic in Honey bees Driven by Varroa Mites. Science 2016, 351, 594-597. [CrossRef] [PubMed]

86. Martin, S.J.; Brettell, L.E. Deformed Wing Virus in Honey bees and Other Insects. Annu. Rev. Virol. 2019, 6, 49-69. [CrossRef] [PubMed]

87. Martin, S.J.; Highfield, A.C.; Brettell, L.; Villalobos, E.M.; Budge, G.E.; Powell, M.; Nikaido, S.; Schroeder, D.C. Global Honey Bee Viral Landscape Altered by a Parasitic Mite. Science 2012, 336, 1304-1306. [CrossRef] [PubMed]

88. Ryabov, E.V.; Wood, G.R.; Fannon, J.M.; Moore, J.D.; Bull, J.C.; Chandler, D.; Mead, A.; Burroughs, N.; Evans, D.J. A Virulent Strain of Deformed Wing Virus (DWV) of Honey bees (Apis mellifera) Prevails after Varroa destructor-Mediated, or In Vitro, Transmission. PLoS Pathog. 2014, 10, e1004230. [CrossRef] [PubMed]

89. Grindrod, I.; Kevill, J.L.; Villalobos, E.M.; Schroeder, D.C.; Martin, S.J. Ten Years of Deformed Wing Virus (DWV) in Hawaiian Honey Bees (Apis mellifera), the Dominant DWV-A Variant Is Potentially Being Replaced by Variants with a DWV-B Coding Sequence. Viruses 2021, 13, 969. [CrossRef]

90. Berryman, A.A. The Orgins and Evolution of Predator-Prey Theory. Ecology 1992, 73, 1530-1535. [CrossRef]

91. Annoscia, D.; Brown, S.P.; Di Prisco, G.; De Paoli, E.; Del Fabbro, S.; Frizzera, D.; Zanni, V.; Galbraith, D.A.; Caprio, E.; Grozinger, C.M.; et al. Haemolymph Removal by Varroa Mite Destabilizes the Dynamical Interaction between Immune Effectors and Virus in Bees, as Predicted by Volterra's Model. Proc. R Soc. B 2019, 286, 20190331. [CrossRef]

92. Zhao, Y.; Heerman, M.; Peng, W.; Evans, J.D.; Rose, R.; DeGrandi-Hoffman, G.; Simone-Finstrom, M.; Li, J.; Li, Z.; Cook, S.C.; et al. The Dynamics of Deformed Wing Virus Concentration and Host Defensive Gene Expression after Varroa Mite Parasitism in Honey Bees, Apis mellifera. Insects 2019, 10, 16. [CrossRef]

93. Ingwell, L.L.; Eigenbrode, S.D.; Bosque-Pérez, N.A. Plant Viruses Alter Insect Behavior to Enhance Their Spread. Sci. Rep. 2012, 2, 578. [CrossRef]

94. Campbell, E.M.; Budge, G.E.; Watkins, M.; Bowman, A.S. Transcriptome Analysis of the Synganglion from the Honey Bee Mite, Varroa destructor and RNAi Knockdown of Neural Peptide Targets. Insect Biochem. Mol. Biol. 2016, 70, 116-126. [CrossRef]

95. Wharton, R.; Roulston, W.; Utech, K.; Kerr, J. Assessment of the Efficiency of Acaricides and Their Mode of Application against the Cattle Tick (Boophilus microplus). Aust. J. Agric. Res. 1970, 21, 985. [CrossRef]

96. Marchetti, S.; Barbattini, R.; D’Agaru, M. Comparative Effectiveness of Treatments Used to Control Varroa jacobsoni oud. Apidologie 1984, 15, 363-378. [CrossRef]

97. Evans, P.D.; Gee, J.D. Action of Formamidine Pesticides on Octopamine Receptors. Nature 1980, 287, 60-62. [CrossRef]

98. Dudai, Y.; Buxbaum, J.; Corfas, G.; Ofarim, M. Formamidines Interact With Drosophila Octopamine Receptors, Alter the Flies' Behavior and Reduce Their Learning Ability. J. Comp. Physiol. 1987, 161, 739-746. [CrossRef]

99. González-Cabrera, J.; Davies, T.G.E.; Field, L.M.; Kennedy, P.J.; Williamson, M.S. An Amino Acid Substitution (L925V) Associated with Resistance to Pyrethroids in Varroa destructor. PLoS ONE 2013, 8, e82941. [CrossRef] [PubMed]

100. Casteels, P.; Ampe, C.; Jacobs, F.; Tempst, P. Functional and Chemical Characterization of Hymenoptaecin, an Antibacterial Polypeptide That Is Infection-Inducible in the Honey bee (Apis mellifera). J. Biol. Chem. 1993, 268, 7044-7054. [CrossRef]

101. Garrido, P.M.; Antúnez, K.; Martín, M.; Porrini, M.P.; Zunino, P.; Eguaras, M.J. Immune-Related Gene Expression in Nurse Honey Bees (Apis mellifera) Exposed to Synthetic Acaricides. J. Insect Physiol. 2013, 59, 113-119. [CrossRef]

102. Gashout, H.A.; Goodwin, P.H.; Guzman-Novoa, E. Lethality of Synthetic and Natural Acaricides to Worker Honey Bees (Apis mellifera) and Their Impact on the Expression of Health and Detoxification-Related Genes. Environ. Sci. Pollut. Res. 2018, 25, 34730-34739. [CrossRef]

103. Fukuto, T.R. Mechanism of Action of Organophosphorus and Carbamate Insecticides. Environ. Health Perspect. 1990, 87, 245-254. [CrossRef] [PubMed]

104. Belzunces, L.P.; Tchamitchian, S.; Brunet, J.-L. Neural Effects of Insecticides in the Honey Bee. Apidologie 2012, 43, 348-370. [CrossRef]

105. Rix, R.R.; Christopher Cutler, G. Acute Exposure to Worst-Case Concentrations of Amitraz Does Not Affect Honey Bee Learning, Short-Term Memory, or Hemolymph Octopamine Levels. J. Econ. Entomol. 2016, tow250. [CrossRef]

106. Gashout, H.A.; Guzman-Novoa, E.; Goodwin, P.H.; Correa-Benítez, A. Impact of Sublethal Exposure to Synthetic and Natural Acaricides on Honey Bee (Apis mellifera) Memory and Expression of Genes Related to Memory. J. Insect Physiol. 2020, $121,104014$. [CrossRef]

107. Frost, E.H.; Shutler, D.; Hillier, N.K. Effects of Fluvalinate on Honey Bee Learning, Memory, Responsiveness to Sucrose, and Survival. J. Exp. Biol. 2013, 216, 2931-2938. [CrossRef]

108. Hillier, N.K.; Frost, E.H.; Shutler, D. Fate of Dermally Applied Miticides Fluvalinate and Amitraz Within Honey Bee (Hymenoptera: Apidae) Bodies. Jnl. Econ. Entom. 2013, 106, 558-565. [CrossRef]

109. Kast, C.; Kilchenmann, V.; Charrière, J. Long-term Monitoring of Lipophilic Acaricide Residues in Commercial SwISS Beeswax. Pest Manag. Sci. 2021, ps.6427. [CrossRef]

110. Ziegelmann, B.; Abele, E.; Hannus, S.; Beitzinger, M.; Berg, S.; Rosenkranz, P. Lithium Chloride Effectively Kills the Honey Bee Parasite Varroa destructor by a Systemic Mode of Action. Sci. Rep. 2018, 8, 683. [CrossRef] 
111. Kolics, É.; Mátyás, K.; Taller, J.; Specziár, A.; Kolics, B. Contact Effect Contribution to the High Efficiency of Lithium Chloride Against the Mite Parasite of the Honey Bee. Insects 2020, 11, 333. [CrossRef]

112. Kolics, É.; Specziár, A.; Taller, J.; Mátyás, K.K.; Kolics, B. Lithium Chloride Outperformed Oxalic Acid Sublimation in a Preliminary Experiment for Varroa Mite Control in Pre-Wintering Honey Bee Colonies. Acta Vet. Hung. 2021, 68, 370-373. [CrossRef] [PubMed]

113. Kolics, É.; Sajtos, Z.; Mátyás, K.; Szepesi, K.; Solti, I.; Németh, G.; Taller, J.; Baranyai, E.; Specziár, A.; Kolics, B. Changes in Lithium Levels in Bees and Their Products Following Anti-Varroa Treatment. Insects 2021, 12, 579. [CrossRef] [PubMed]

114. Ritter, W. Varroa Disease of the Honey bee Apis mellifera. Bee World 1981, 62, 141-153. [CrossRef]

115. Calis, J.N.M.; Beetsma, J.; Boot, W.J.; van den Eijnde, J.; de Ruijter, A. Control of the Varroa Mite by Treatment of Sealed Honey bee Brood with Formic Acid. Proc. Sect. Exp. Appl. Entomol. Neth. Entomol. Soc. 1993, 4, 217-222.

116. Keyhani, J.; Keyhani, E. Epr Study of the Effect of Formate on Cytochrome c Oxidase. Biochem. Biophys. Res. Commun. 1980, 92, 327-333. [CrossRef]

117. Genath, A.; Sharbati, S.; Buer, B.; Nauen, R.; Einspanier, R. Comparative Transcriptomics Indicates Endogenous Differences in Detoxification Capacity after Formic Acid Treatment between Honey Bees and Varroa Mites. Sci. Rep. 2020, 10, 21943. [CrossRef] [PubMed]

118. Hansen, H.; Guldborg, M. Guldborg Residues in Honey and Wax after Treatment of Bee Colonies with Formic Acid. Tidsskr. Planteavl 1988, 92, 7-10.

119. Bogdanov, S.; Charrière, J.-D.; Imdorf, A.; Kilchenmann, V.; Fluri, P. Determination of Residues in Honey after Treatments with Formic and Oxalic Acid under Field Conditions. Apidologie 2002, 33, 399-409. [CrossRef]

120. Satta, A.; Floris, I.; Eguaras, M.; Cabras, P.; Garau, V.L.; Melis, M. Formic Acid-Based Treatments for Control of Varroa destructor in a Mediterranean Area. J. Econ. Entomol. 2005, 98, 267-273. [CrossRef] [PubMed]

121. Calis, J.N.M.; Boot, W.J.; Beetsma, J.; van den Eijnde, J.H.P.M.; de Ruijter, A.; van der Steen, J.J.M. Control of Varroa by Combining Trapping in Honey Bee Worker Brood with Formic Acid Treatment of the Capped Brood Outside the Colony: Putting Knowledge on Brood Cell Invasion into Practice. J. Apic. Res. 1998, 37, 205-215. [CrossRef]

122. Eguaras, M.; Palacio, M.A.; Faverin, C.; Basualdo, M.; Del Hoyo, M.L.; Velis, G.; Bedascarrasbure, E. Efficacy of Formic Acid in Gel for Varroa Control in Apis mellifera L.: Importance of the Dispenser Position inside the Hive. Vet. Parasitol. 2003, 111, 241-245. [CrossRef]

123. Pietropaoli, M.; Formato, G. Liquid Formic Acid 60\% to Control Varroa Mites (Varroa destructor) in Honey Bee Colonies (Apis mellifera): Protocol Evaluation. J. Apic. Res. 2018, 57, 300-307. [CrossRef]

124. Steube, X.; Beinert, P.; Kirchner, W.H. Efficacy and Temperature Dependence of $60 \%$ and $85 \%$ Formic Acid Treatment against Varroa destructor. Apidologie 2021, 52, 720-729. [CrossRef]

125. Elzen, P.J.; Westervelt, D.; Lucas, R. Formic Acid Treatment for Control of Varroa destructor (Mesostigmata: Varroidae) and Safety to Apis mellifera (Hymenoptera: Apidae) Under Southern United States Conditions. Oxf. Acad. J. 2004, 97, 1509-1512. [CrossRef] [PubMed]

126. Bolli, H.K.; Bogdanov, S.; Imdorf, A.; Fluri, P. Zur Wirkungsweise von Ameisensäure Bei Varroa jacobsoni oud Und Der Honigbiene (Apis mellifera L.). Apidologie 1993, 24, 51-57. [CrossRef]

127. Westcott, L.C.; Winston, M.L. Chemical Acaricides in Apis mellifera (Hymenoptera: Apidae) Colonies; Do They Cause Non-Lethal Effects? Can. Entomol. 1999, 131, 363-371. [CrossRef]

128. Eguaras, M.; Del Hoyo, M.; Palacio, M.A.; Ruffinengo, S.; Bedascarrasbure, E.L. A New Product with Formic Acid for Varroa jacobsoni oud. Control in Argentina. I. Efficacy: Efficacy of New Product for V. jacobsoni Control. J. Vet. Med. Ser. B 2008, $48,11-14$. [CrossRef]

129. Mutinelli, F.; Baggio, A.; Capolongo, F.; Piro, R.; Prandin, L.; Biasion, L. A Scientific Note on Oxalic Acid by Topical Application for the Control of Varroosis. Apidologie 1997, 28, 461-462. [CrossRef]

130. Charriére, J.-D.; Imdorf, A. Oxalic Acid Treatment by Trickling against Varroa destructor: Recommendations for Use in Central Europe and under Temperate Climate Conditions. Bee World 2002, 83, 51-60. [CrossRef]

131. Rademacher, E.; Harz, M. Oxalic Acid for the Control of Varroosis in Honey Bee Colonies-A Review. Apidologie 2006, 37, 98-120. [CrossRef]

132. Maggi, M.D.; Damiani, N.; Ruffinengo, S.R.; Brasesco, M.C.; Szawarski, N.; Mitton, G.; Mariani, F.; Sammataro, D.; Quintana, S.; Eguaras, M.J. The Susceptibility of Varroa destructor against Oxalic Acid: A Study Case. Bull. Insectol. 2017, 70, 39-44.

133. Gregorc, A.; Planinc, I. Acaricidal Effect of Oxalic Acid in Honey bee(Apis mellifera) Colonies. Apidologie 2001, 32, 333-340. [CrossRef]

134. Gregorc, A.; Planinc, I. The Control of Varroa destructor Using Oxalic Acid. Vet. J. 2002, 163, 306-310. [CrossRef]

135. Papežíková, I.; Palíková, M.; Kremserová, S.; Zachová, A.; Peterová, H.; Babák, V.; Navrátil, S. Effect of Oxalic Acid on the Mite Varroa destructor and Its Host the Honey Bee Apis Mellifera. J. Apic. Res. 2017, 56, 400-408. [CrossRef]

136. Maddaloni, M.; Pascual, D.W. Isolation of Oxalotrophic Bacteria Associated with Varroa destructor Mites. Lett. Appl. Microbiol. 2015, 61, 411-417. [CrossRef]

137. Martín-Hernández, R.; Higes, M.; Pérez, J.L.; Nozal, M.J.; Gómez, L.; Meana, A. Short Term Negative Effect of Oxalic Acid in Apis mellifera iberiensis. Span. J. Agric. Res. 2007, 5, 474. [CrossRef]

138. Schneider, S.; Eisenhardt, D.; Rademacher, E. Sublethal Effects of Oxalic Acid on Apis mellifera (Hymenoptera: Apidae): Changes in Behaviour and Longevity. Apidologie 2012, 43, 218-225. [CrossRef] 
139. Strachecka, A.; Paleolog, J.; Olszewski, K.; Borsuk, G. Influence of Amitraz and Oxalic Acid on the Cuticle Proteolytic System of Apis mellifera L. Workers. Insects 2012, 3, 821-832. [CrossRef] [PubMed]

140. Rademacher, E.; Harz, M.; Schneider, S. Effects of Oxalic Acid on Apis mellifera (Hymenoptera: Apidae). Insects 2017, 8, 84. [CrossRef] [PubMed]

141. Gregorc, A.; Pogacnik, A.; Bowen, I.D. Cell Death in Honey bee (Apis mellifera) Larvae Treated with Oxalic or Formic Acid. Apidologie 2004, 35, 453-460. [CrossRef]

142. Higes, M.; Meana, A.; Suárez, M.; Llorente, J. Negative Long-Term Effects on Bee Colonies Treated with Oxalic Acid against Varroa jacobsoni oud. Apidologie 1999, 30, 289-292. [CrossRef]

143. Milani, N. Activity of Oxalic and Citric Acidson the Mite Varroa destructor in Laboratory Assays. Apidologie 2001, 32, 127-138. [CrossRef]

144. Van Engelsdorp, D.; Underwood, R.M.; Cox-foster, D.L. Short-Term Fumigation of Honey Bee (Hymenoptera: Apidae) Colonies with Formic and Acetic Acids for the Control of Varroa destructor (Acari: Varroidae). J. Econ. Entomol. 2008, 101, 256-264. [CrossRef]

145. Sofou, K.; Isaakidis, D.; Spyros, A.; Büttner, A.; Giannis, A.; Katerinopoulos, H.E. Use of Costic Acid, a Natural Extract from Dittrichia viscosa, for the Control of Varroa destructor, a Parasite of the European Honey Bee. Beilstein J. Org. Chem. 2017, 13, 952-959. [CrossRef] [PubMed]

146. Cimmino, A.; Freda, F.; Santoro, E.; Superchi, S.; Evidente, A.; Cristofaro, M.; Masi, M. $\alpha$-Costic Acid, a Plant Sesquiterpene with Acaricidal Activity against Varroa destructor Parasitizing the Honey Bee. Nat. Prod. Res. 2019, 35, 1-8. [CrossRef] [PubMed]

147. Georgiladaki, S.; Isaakidis, D.; Spyros, A.; Tsikalas, G.K.; Katerinopoulos, H.E. Enantioselective Synthesis of a Costic Acid Analogue with Acaricidal Activity against the Bee Parasite Varroa destructor. R Soc. Open Sci. 2020, 7, 200612. [CrossRef] [PubMed]

148. McAfee, A.; Chapman, A.; Iovinella, I.; Gallagher-Kurtzke, Y.; Collins, T.F.; Higo, H.; Madilao, L.L.; Pelosi, P.; Foster, L.J. A Death Pheromone, Oleic Acid, Triggers Hygienic Behavior in Honey Bees (Apis mellifera L.). Sci. Rep. 2018, 8, 5719. [CrossRef]

149. Ziegelmann, B.; Tolasch, T.; Steidle, J.L.M.; Rosenkranz, P. The Mating Behavior of Varroa destructor Is Triggered by a Female Sex Pheromone. Part 2: Identification and Dose-Dependent Effects of Components of the Varroa Sex Pheromone. Apidologie 2013, 44, 481-490. [CrossRef]

150. Gashout, H.A.; Guzmán-Novoa, E. Acute Toxicity of Essential Oils and Other Natural Compounds to the Parasitic Mite, Varroa destructor, and to Larval and Adult Worker Honey Bees (Apis mellifera L.). J. Apic. Res. 2009, 48, 263-269. [CrossRef]

151. Imdorf, A.; Bogdanov, S.; Ochoa, R.I.; Calderone, N.W. Use of Essential Oils for the Control of Varroa jacobsoni oud. in Honey Bee Colonies. Apidologie 1999, 30, 209-228. [CrossRef]

152. Floris, I.; Satta, A.; Cabras, P.; Garau, V.L.; Angioni, A. Comparison Between Two Thymol Formulations in the Control of Varroa destructor: Effectiveness, Persistence, and Residues. J. Econ. Entomol. 2004, 97, 187-191. [CrossRef]

153. Chapuy, C.; Ribbens, L.; Renou, M.; Dacher, M.; Armengaud, C. Thymol Affects Congruency Between Olfactory and Gustatory Stimuli in Bees. Sci. Rep. 2019, 9, 7752. [CrossRef]

154. Mondet, F.; Goodwin, M.; Mercer, A. Age-Related Changes in the Behavioural Response of Honey bees to Apiguard ${ }^{\circledR}$, a ThymolBased Treatment Used to Control the Mite Varroa destructor. J. Comp. Physiol. A 2011, 197, 1055-1062. [CrossRef]

155. Blenau, W.; Rademacher, E.; Baumann, A. Plant Essential Oils and Formamidines as Insecticides/Acaricides: What Are the Molecular Targets? Apidologie 2012, 43, 334-347. [CrossRef]

156. Colin, T.; Lim, M.Y.; Quarrell, S.R.; Allen, G.R.; Barron, A.B. Effects of Thymol on European Honey Bee Hygienic Behaviour. Apidologie 2019, 50, 141-152. [CrossRef]

157. Ariana, A. Laboratory Evaluation of Some Plant Essences to Control Varroa destructor (Acari: Varroidae). Exp. Appl. Acarol. 2002, 27, 319-327. [CrossRef]

158. Ebert, T.A.; Kevan, P.G.; Bishop, B.L.; Kevan, S.D.; Downer, R.A. Oral Toxicity of Essential Oils and Organic Acids Fed to Honey Bees (Apis mellifera). J. Apic. Res. 2007, 46, 220-224. [CrossRef]

159. Melathopoulos, A.P.; Winston, M.L.; Whittington, R.; Smith, T.; Lindberg, C.; Mukai, A.; Moore, M. Comparative Laboratory Toxicity of Neem Pesticides to Honey Bees (Hymenoptera: Apidae), Their Mite Parasites Varroa jacobsoni (Acari: Varroidae) and Acarapis woodi (Acari: Tarsonemidae), and Brood Pathogens Paenibacillus larvae and Ascophaera apis. J. Econ. Entomol. 2000, 93, 199-209. [CrossRef] [PubMed]

160. Xavier, V.M.; Message, D.; Picanço, M.C.; Chediak, M.; Júnior, P.A.S.; Ramos, R.S.; Martins, J.C. Acute Toxicity and Sublethal Effects of Botanical Insecticides to Honey Bees. J. Insect Sci. 2015, 15, 137. [CrossRef]

161. DeGrandi-Hoffman, G.; Ahumada, F.; Probasco, G.; Schantz, L. The Effects of Beta Acids from Hops (Humulus lupulus) on Mortality of Varroa destructor (Acari: Varroidae). Exp. Appl. Acarol. 2012, 58, 407-421. [CrossRef]

162. Rademacher, E.; Harz, M.; Schneider, S. The Development of HopGuard ${ }^{\circledR}$ as a Winter Treatment against Varroa destructor in Colonies of Apis mellifera. Apidologie 2015, 46, 748-759. [CrossRef]

163. Boot, W.J.; Tan, N.Q.; Dien, P.C.; Huan, L.V.; Dung, N.V.; Long, L.T.; Beetsma, J. Reproductive Success of Varroa jacobsoni in Brood of Its Original Host, Apis cerana, in Comparison to That of Its New Host, A. mellifera (Hymenoptera: Apidae). Bull. Entomol. Res. 1997, 87, 119-126. [CrossRef]

164. Koeniger, N.; Koeniger, G.; Delfinado-Baker, M. Observations on Mites of the Asian Honey bee Species (Apis cerana, Apis dorsata, Apis florea). Apidologie 1983, 14, 197-204. [CrossRef] 
165. Rosenkranz, P.; Tewarson, N.C.; Singh, A.; Engels, W. Differential Hygienic Behaviour towards Varroa jacobsoni in Capped Worker Brood of Apis cerana Depends on Alien Scent Adhering to the Mites. J. Apic. Res. 1993, 32, 89-93. [CrossRef]

166. Rath, W. Co-Adaptation of Apis cerana Fabr. and Varroa jacobsoni oud. Apidologie 1999, 30, 97-110. [CrossRef]

167. Guichard, M.; Dietemann, V.; Neuditschko, M.; Dainat, B. Advances and Perspectives in Selecting Resistance Traits against the Parasitic Mite Varroa destructor in Honey Bees. Genet Sel. Evol. 2020, 52, 71. [CrossRef]

168. Mondet, F.; Beaurepaire, A.; McAfee, A.; Locke, B.; Alaux, C.; Blanchard, S.; Danka, B.; Le Conte, Y. Honey Bee Survival Mechanisms against the Parasite Varroa destructor: A Systematic Review of Phenotypic and Genomic Research Efforts. Int. J. Parasitol. 2020, 50, 433-447. [CrossRef]

169. Van Alphen, J.J.M.; Fernhout, B.J. Natural Selection, Selective Breeding, and the Evolution of Resistance of Honey bees (Apis mellifera) against Varroa. Zool. Lett. 2020, 6, 6. [CrossRef] [PubMed]

170. Maggi, M.D.; Ruffinengo, S.R.; Mendoza, Y.; Ojeda, P.; Ramallo, G.; Floris, I.; Eguaras, M.J. Susceptibility of Varroa destructor (Acari: Varroidae) to Synthetic Acaricides in Uruguay: Varroa Mites' Potential to Develop Acaricide Resistance. Parasitol. Res. 2011, 108, 815-821. [CrossRef] [PubMed]

171. Sammataro, D.; Untalan, P.; Guerrero, F.; Finley, J. The Resistance of Varroa Mites (Acari: Varroidae) to Acaricides and the Presence of Esterase. Int. J. Acarol. 2005, 31, 67-74. [CrossRef]

172. Meikle, W.G.; Sammataro, D.; Neumann, P.; Pflugfelder, J. Challenges for Developing Pathogen-Based Biopesticides against Varroa destructor (Mesostigmata: Varroidae). Apidologie 2012, 43, 501-514. [CrossRef]

173. Akimov, I.A.; Benedyk, S.V.; Zaloznaya, L.M. Complex Analysis of Morphological Characters of Gamasid Mite Varroa destructor (Parasitiformes, Varroidae). Vestn. Zool. 2004, 38, 57-66.

174. Yevstafieva, V.O.; Zaloznaya, L.M.; Nazarenko, O.S.; Melnychuk, V.V.; Sobolta, A.G. Morphological Variation of Varroa destructor (Parasitiformes, Varroidae) in Different Seasons. Biosys. Divers. 2020, 28, 18-23. [CrossRef]

175. Noël, A.; Le Conte, Y.; Mondet, F. Varroa Destructor: How Does It Harm Apis mellifera Honey Bees and What Can Be Done about It? Emerg. Top. Life Sci. 2020, 4, 45-57. [CrossRef]

176. Gregorc, A. Monitoring of Honey Bee Colony Losses: A Special Issue. Diversity 2020, 12, 403. [CrossRef]

177. Colin, T.; Monchanin, C.; Lihoreau, M.; Barron, A.B. Pesticide Dosing Must Be Guided by Ecological Principles. Nat. Ecol. Evol. 2020, 4, 1575-1577. [CrossRef] [PubMed]

178. Giacomelli, A.; Pietropaoli, M.; Carvelli, A.; Iacoponi, F.; Formato, G. Combination of Thymol Treatment (Apiguard $\left.{ }^{\circledR}\right)$ and Caging the Queen Technique to Fight Varroa destructor. Apidologie 2016, 47, 606-616. [CrossRef]

179. Büchler, R.; Uzunov, A.; Kovačić, M.; Prešern, J.; Pietropaoli, M.; Hatjina, F.; Pavlov, B.; Charistos, L.; Formato, G.; Galarza, E.; et al. Summer Brood Interruption as Integrated Management Strategy for Effective Varroa Control in Europe. J. Apic. Res. 2020, 59, 764-773. [CrossRef]

180. Lodesani, M.; Costa, C.; Besana, A.; Dall'Olio, R.; Franceschetti, S.; Tesoriero, D.; Giacomo, D. Impact of Control Strategies for Varroa destructor on Colony Survival and Health in Northern and Central Regions of Italy. J. Apic. Res. 2014, 53, 155-164. [CrossRef]

181. Gregorc, A.; Alburaki, M.; Werle, C.; Knight, P.R.; Adamczyk, J. Brood Removal or Queen Caging Combined with Oxalic Acid Treatment to Control Varroa Mites (Varroa destructor) in Honey Bee Colonies (Apis mellifera). Apidologie 2017, 48, 821-832. [CrossRef]

182. Lodesani, M.; Franceschetti, S.; Dall'Ollio, R. Evaluation of Early Spring Bio-Technical Management Techniques to Control Varroosis in Apis mellifera. Apidologie 2019, 50, 131-140. [CrossRef]

183. Jack, C.J.; van Santen, E.; Ellis, J.D. Evaluating the Efficacy of Oxalic Acid Vaporization and Brood Interruption in Controlling the Honey Bee Pest Varroa destructor (Acari: Varroidae). J. Econ. Entomol. 2020, 113, 582-588. [CrossRef]

184. Gregorc, A.; Sampson, B. Diagnosis of Varroa Mite (Varroa destructor) and Sustainable Control in Honey Bee (Apis mellifera) Colonies-A Review. Diversity 2019, 11, 243. [CrossRef]

185. Mancuso, T.; Croce, L.; Vercelli, M. Total Brood Removal and Other Biotechniques for the Sustainable Control of Varroa Mites in Honey Bee Colonies: Economic Impact in Beekeeping Farm Case Studies in Northwestern Italy. Sustainability 2020, 12, 2302. [CrossRef]

186. Fagan, L.L.; Nelson, W.R.; Meenken, E.D.; Howlett, B.G.; Walker, M.K.; Donovan, B.J. Varroa Management in Small Bites: Varroa Management in Small Bites. J. Appl. Entomol. 2012, 136, 473-475. [CrossRef]

187. van Toor, R.F.; Thompson, S.E.; Gibson, D.M.; Smith, G.R. Ingestion of Varroa destructor by Pseudoscorpions in Honey Bee Hives Confirmed by PCR Analysis. J. Apic. Res. 2015, 54, 555-562. [CrossRef]

188. Weygoldt, P. Paarungsverhalten Und Samenübertragung Beim Pseudoskorpion Withius Subruber Simon (Cheliferidae). Z. Für Tierpsychol. 1969, 26, 230-235. [CrossRef]

189. Donovan, B.J.; Paul, F. Pseudoscorpions: The Forgotten Beneficials inside Beehives and Their Potential for Management for Control of Varroa and Other Arthropod Pests. Bee World 2005, 86, 83-87. [CrossRef]

190. Read, S.; Howlett, B.G.; Donovan, B.J.; Nelson, W.R.; van Toor, R.F. Culturing Chelifers (Pseudoscorpions) That Consume Varroa Mites. J. Appl. Entomol. 2014, 138, 260-266. [CrossRef]

191. Rondeau, S.; Giovenazzo, P.; Fournier, V. Risk Assessment and Predation Potential of Stratiolaelaps Scimitus (Acari: Laelapidae) to Control Varroa destructor (Acari: Varroidae) in Honey Bees. PLoS ONE 2018, 13, e0208812. [CrossRef] 
192. Rangel, J.; Ward, L. Evaluation of the Predatory Mite Stratiolaelaps scimitus for the Biological Control of the Honey Bee Ectoparasitic Mite Varroa destructor. J. Apic. Res. 2018, 57, 425-432. [CrossRef]

193. Rondeau, S.; Giovenazzo, P.; Fournier, V. The Use of the Predatory Mite Stratiolaelaps scimitus (Mesostigmata: Laelapidae) to Control Varroa destructor (Mesostigmata: Varroidae) in Honey Bee Colonies in Early and Late Fall. J. Econ. Entomol. 2019, 112, 534-542. [CrossRef]

194. Chandler, D.; Sunderland, K.D.; Ball, B.V.; Davidson, G. Prospective Biological Control Agents of Varroa destructor n. Sp., an Important Pest of the European Honey bee, Apis mellifera. Biocontrol Sci. Technol. 2001, 11, 429-448. [CrossRef]

195. Hubert, J.; Bicianova, M.; Ledvinka, O.; Kamler, M.; Lester, P.J.; Nesvorna, M.; Kopecky, J.; Erban, T. Changes in the Bacteriome of Honey Bees Associated with the Parasite Varroa destructor, and Pathogens Nosema and Lotmaria Passim. Microb. Ecol. 2017, 73, 685-698. [CrossRef] [PubMed]

196. Marche, M.G.; Satta, A.; Floris, I.; Pusceddu, M.; Buffa, F.; Ruiu, L. Quantitative Variation in the Core Bacterial Community Associated with Honey Bees from Varroa-Infested Colonies. J. Apic. Res. 2019, 58, 444-454. [CrossRef]

197. Sandionigi, A.; Vicario, S.; Prosdocimi, E.M.; Galimberti, A.; Ferri, E.; Bruno, A.; Balech, B.; Mezzasalma, V.; Casiraghi, M. Towards a Better Understanding of Apis mellifera and Varroa destructor Microbiomes: Introducing 'PHYLOH' as a Novel Phylogenetic Diversity Analysis Tool. Mol. Ecol. Resour. 2015, 15, 697-710. [CrossRef] [PubMed]

198. Dillon, R.J.; Dillon, V.M. The Gut Bacteria of Insects: Nonpathogenic Interactions. Annu. Rev. Entomol. 2004, 49, 71-92. [CrossRef]

199. Leonard, S.P.; Powell, J.E.; Perutka, J.; Geng, P.; Heckmann, L.C.; Horak, R.D.; Davies, B.W.; Ellington, A.D.; Barrick, J.E.; Moran, N.A. Engineered Symbionts Activate Honey Bee Immunity and Limit Pathogens. Science 2020, 367, 573-576. [CrossRef]

200. Saccà, M.L.; Lodesani, M. Isolation of Bacterial Microbiota Associated to Honey Bees and Evaluation of Potential Biocontrol Agents of Varroa destructor. Benef. Microbes 2020, 11, 641-654. [CrossRef]

201. Evans, J.D.; Lopez, D.L. Bacterial Probiotics Induce an Immune Response in the Honey Bee (Hymenoptera: Apidae). J. Econ. Entomol. 2004, 97, 752-756. [CrossRef] [PubMed]

202. Maggi, M.; Negri, P.; Plischuk, S.; Szawarski, N.; De Piano, F.; De Feudis, L.; Eguaras, M.; Audisio, C. Effects of the Organic Acids Produced by a Lactic Acid Bacterium in Apis mellifera Colony Development, Nosema ceranae Control and Fumagillin Efficiency. Vet. Microbiol. 2013, 167, 474-483. [CrossRef]

203. Daisley, B.A.; Pitek, A.P.; Chmiel, J.A.; Al, K.F.; Chernyshova, A.M.; Faragalla, K.M.; Burton, J.P.; Thompson, G.J.; Reid, G. Novel Probiotic Approach to Counter Paenibacillus larvae Infection in Honey Bees. ISME J. 2020, 14, 476-491. [CrossRef]

204. Sabaté, D.C.; Cruz, M.S.; Benítez-Ahrendts, M.R.; Audisio, M.C. Beneficial Effects of Bacillus subtilis sub Sp. Subtilis Mori 2, a Honey-Associated Strain, on Honey bee Colony Performance. Probiotics Antimicro. Prot. 2012, 4, 39-46. [CrossRef]

205. Audisio, M.C. Gram-Positive Bacteria with Probiotic Potential for the Apis mellifera L. Honey Bee: The Experience in the Northwest of Argentina. Probiotics Antimicro. Prot. 2017, 9, 22-31. [CrossRef]

206. De Piano, F.G.; Maggi, M.D.; Meroi Arceitto, F.R.; Audisio, M.C.; Eguaras, M.; Ruffinengo, S.R. Effects of Bacterial Cell-Free Supernatant on Nutritional Parameters of Apis mellifera and Their Toxicity Against Varroa destructor. J. Apic. Sci. 2020, 64, 55-66. [CrossRef]

207. Manici, L.M.; Saccà, M.L.; Lodesani, M. Secondary Metabolites Produced by Honey Bee-Associated Bacteria for Apiary Health: Potential Activity of Platynecine. Curr. Microbiol. 2020, 77, 3441-3449. [CrossRef] [PubMed]

208. Bravo, A.; Likitvivatanavong, S.; Gill, S.S.; Soberón, M. Bacillus thuringiensis: A Story of a Successful Bioinsecticide. Insect Biochem. Mol. Biol. 2011, 41, 423-431. [CrossRef]

209. Jouzani, G.S.; Valijanian, E.; Sharafi, R. Bacillus thuringiensis: A Successful Insecticide with New Environmental Features and Tidings. Appl. Microbiol. Biotechnol. 2017, 101, 2691-2711. [CrossRef]

210. Angus, T.A.; Norris, J.R. A Comparison of the Toxicity of Some Varieties of Bacillus thuringiensis Berliner for Silkworm Larvae. J. Invertebr. Pathol. 1968, 11, 289-295. [CrossRef]

211. Tsagou, V.; Lianou, A.; Lazarakis, D.; Emmanouel, N.; Aggelis, G. Newly Isolated Bacterial Strains Belonging to Bacillaceae (Bacillus Sp.) and Micrococcaceae Accelerate Death of the Honey Bee Mite, Varroa destructor (V. jacobsoni), in Laboratory Assays. Biotechnol. Lett. 2004, 26, 529-532. [CrossRef] [PubMed]

212. Bravo, A.; Gill, S.S.; Soberón, M. Mode of Action of Bacillus thuringiensis Cry and Cyt Toxins and Their Potential for Insect Control. Toxicon 2007, 49, 423-435. [CrossRef]

213. Alquisira-Ramírez, E.V.; Paredes-Gonzalez, J.R.; Hernández-Velázquez, V.M.; Ramírez-Trujillo, J.A.; Peña-Chora, G. In Vitro Susceptibility of Varroa destructor and Apis mellifera to Native Strains of Bacillus thuringiensis. Apidologie 2014, 45, 707-718. [CrossRef]

214. Libardoni, G.; Neves, P.M.O.J.; Abati, R.; Sampaio, A.R.; Costa-Maia, F.M.; de Souza Vismara, E.; Lozano, E.R.; Potrich, M. Possible Interference of Bacillus thuringiensis in the Survival and Behavior of Africanized Honey Bees (Apis mellifera). Sci. Rep. 2021, 11, 3482. [CrossRef]

215. Steinigeweg, C.; Alkassab, A.T.; Beims, H.; Eckert, J.H.; Richter, D.; Pistorius, J. Assessment of the Impacts of Microbial Plant Protection Products Containing Bacillus thuringiensis on the Survival of Adults and Larvae of the Honey bee (Apis mellifera). Environ. Sci. Pollut. Res. 2021. [CrossRef]

216. Jurat-Fuentes, J.L.; Heckel, D.G.; Ferré, J. Mechanisms of Resistance to Insecticidal Proteins from Bacillus thuringiensis. Annu. Rev. Entomol. 2021, 66, 121-140. [CrossRef] 
217. Chandler, D.; Davidson, G.; Pell, J.K.; Ball, B.V.; Shaw, K.; Sunderland, K.D. Fungal Biocontrol of Acari. Biocontrol Sci. Technol. 2000, 10, 357-384. [CrossRef]

218. Frazzon, A.P.G.; Vaz Junior, I.d.S.; Masuda, A.; Schrank, A.; Vainstein, M.H. In Vitro Assessment of Metarhizium anisopliae Isolates to Control the Cattle Tick Boophilus microplus. Vet. Parasitol. 2000, 94, 117-125. [CrossRef]

219. Roy, H.E.; Steinkraus, D.C.; Eilenberg, J.; Hajek, A.E.; Pell, J.K. Bizarre Interactions and Endgames: Entomopathogenic Fungi and Their Arthropod Hosts. Annu. Rev. Entomol. 2006, 51, 331-357. [CrossRef]

220. Kanga, L.H.B.; James, R.R.; Boucias, D.G. Hirsutella thompsonii and Metarhizium anisopliae as Potential Microbial Control Agents of Varroa destructor, a Honey Bee Parasite. J. Invertebr. Pathol. 2002, 81, 175-184. [CrossRef]

221. Kanga, L.H.B.; Jones, W.A.; James, R.R. Field Trials Using the Fungal Pathogen, Metarhizium anisopliae (Deuteromycetes: Hyphomycetes) to Control the Ectoparasitic Mite, Varroa destructor (Acari: Varroidae) in Honey Bee, Apis mellifera (Hymenoptera: Apidae) Colonies. J. Econ. Entomol. 2003, 96, 1091-1099. [CrossRef] [PubMed]

222. Kanga, L.H.B.; Jones, W.A.; Gracia, C. Efficacy of Strips Coated with Metarhizium anisopliae for Control of Varroa destructor (Acari: Varroidae) in Honey Bee Colonies in Texas and Florida. Exp. Appl. Acarol. 2007, 40, 249-258. [CrossRef] [PubMed]

223. Kanga, L.H.B.; Adamczyk, J.; Patt, J.; Gracia, C.; Cascino, J. Development of a User-Friendly Delivery Method for the Fungus Metarhizium anisopliae to Control the Ectoparasitic Mite Varroa destructor in Honey Bee, Apis mellifera, Colonies. Exp. Appl. Acarol. 2010, 52, 327-342. [CrossRef] [PubMed]

224. Rodríguez, M.; Gerding, M.; France, A.; Ceballos, R. Evaluation of Metarhizium anisopliae var. Anisopliae Qu-M845 Isolate to Control Varroa destructor (Acari: Varroidae) in Laboratory and Field Trials. Chilean J. Agric. Res. 2009, 69. [CrossRef]

225. Reinbacher, L.; Fernández-Ferrari, M.C.; Angeli, S.; Schausberger, P. Effects of Metarhizium anisopliae on Host Choice of the Bee-Parasitic Mite Varroa destructor. Acarologia 2018, 58, 287-295. [CrossRef]

226. Fernandez Ferrari, M.C.; Favaro, R.; Mair, S.; Zanotelli, L.; Malagnini, V.; Fontana, P.; Angeli, S. Application of Metarhizium anisopliae as a Potential Biological Control of Varroa destructor in Italy. J. Apic. Res. 2020, 59, 528-538. [CrossRef]

227. Hamiduzzaman, M.M.; Sinia, A.; Guzman-Novoa, E.; Goodwin, P.H. Entomopathogenic Fungi as Potential Biocontrol Agents of the Ecto-Parasitic Mite, Varroa destructor, and Their Effect on the Immune Response of Honey Bees (Apis mellifera L.). J. Invertebr. Pathol. 2012, 111, 237-243. [CrossRef]

228. Han, J.O.; Naeger, N.L.; Hopkins, B.K.; Sumerlin, D.; Stamets, P.E.; Carris, L.M.; Sheppard, W.S. Directed Evolution of Metarhizium fungus Improves Its Biocontrol Efficacy against Varroa Mites in Honey Bee Colonies. Sci. Rep. 2021, 11, 10582. [CrossRef]

229. Steenberg, T.; Kryger, P.; Holst, N. A Scientific Note on the Fungus Beauveria bassiana Infecting Varroa destructor in Worker Brood Cells in Honey Bee Hives. Apidologie 2010, 41, 127-128. [CrossRef]

230. Meikle, W.G.; Mercadier, G.; Holst, N.; Nansen, C.; Girod, V. Duration and Spread of an Entomopathogenic Fungus, Beauveria bassiana (Deuteromycota: Hyphomycetes), Used to Treat Varroa Mites (Acari: Varroidae) in Honey Bee (Hymenoptera: Apidae) Hives. J. Econ. Entomol. 2007, 100, 1-10. [CrossRef]

231. Meikle, W.G.; Mercadier, G.; Holst, N.; Nansen, C.; Girod, V. Impact of a Treatment of Beauveria bassiana (Deuteromycota: Hyphomycetes) on Honey bee (Apis mellifera) Colony Health and on Varroa destructor Mites (Acari: Varroidae). Apidologie 2008, 39, 247-259. [CrossRef]

232. Colombo, F.C.; Maciel, R.M.A.; Abati, R.; Raulino-Domanski, F.; Longhi, S.J.; Costa-Maia, F.M.; de Souza Vismara, E.; Lozano, E.R.; Potrich, M. Do Beauveria bassiana and Metarhizium anisopliae Affect Worker Survival and the Production of Africanized Apis mellifera Queens? J. Apic. Res. 2020, 1-10. [CrossRef]

233. Campbell, E.M.; Budge, G.E.; Bowman, A.S. Gene-Knockdown in the Honey Bee Mite Varroa destructor by a Non-Invasive Approach: Studies on a Glutathione S-Transferase. Parasites Vectors 2010, 3, 73. [CrossRef] [PubMed]

234. Garbian, Y.; Maori, E.; Kalev, H.; Shafir, S.; Sela, I. Bidirectional Transfer of RNAi between Honey Bee and Varroa destructor: Varroa Gene Silencing Reduces Varroa Population. PLoS Pathog. 2012, 8, e1003035. [CrossRef] [PubMed]

235. Singh, N.K.; Eliash, N.; Stein, I.; Kamer, Y.; Ilia, Z.; Rafaeli, A.; Soroker, V. Identification and Gene-Silencing of a Putative Odorant Receptor Transcription Factor in Varroa destructor: Possible Role in Olfaction: Putative Varroa destructor Odorant Receptor Transcription Factor. Insect Mol. Biol. 2016, 25, 181-190. [CrossRef] [PubMed]

236. Huang, Z.Y.; Bian, G.; Xi, Z.; Xie, X. Genes Important for Survival or Reproduction in Varroa destructor Identified by RNAi: Varroa destructor RNAi. Insect Sci. 2019, 26, 68-75. [CrossRef] [PubMed]

237. Yoder, J.A.; Sammataro, D. Potential to Control Varroa Mites (Acari: Varroidae) Using Chemical Ecology. Int. J. Acarol. 2003, 29, 139-143. [CrossRef]

238. Light, M.; Shutler, D.; Cutler, G.C.; Hillier, N.K. Electrotarsogram Responses to Synthetic Odorants by Varroa destructor, a Primary Parasite of Western Honey Bees (Apis mellifera). Exp. Appl. Acarol. 2020, 81, 515-530. [CrossRef]

239. Lihoreau, M.; Dubois, T.; Gomez-Moracho, T.; Kraus, S.; Monchanin, C.; Pasquaretta, C. Putting the ecology back into insect cognition research. In Advances in Insect Physiology; Elsevier: Amsterdam, The Netherlands, 2019; Volume 57, pp. 1-25, ISBN 978-0-12-818660-2.

240. Noskov, A.; Bendix, J.; Friess, N. A Review of Insect Monitoring Approaches with Special Reference to Radar Techniques. Sensors 2021, 21, 1474. [CrossRef] [PubMed]

241. Dietemann, V.; Pflugfelder, J.; Anderson, D.; Charrière, J.-D.; Chejanovsky, N.; Dainat, B.; de Miranda, J.; Delaplane, K.; Dillier, F.-X.; Fuch, S.; et al. Varroa destructor: Research Avenues towards Sustainable Control. J. Apic. Res. 2012, 51, 125-132. [CrossRef] 
242. Egekwu, N.I.; Posada, F.; Sonenshine, D.E.; Cook, S. Using an in Vitro System for Maintaining Varroa destructor Mites on Apis mellifera Pupae as Hosts: Studies of Mite Longevity and Feeding Behavior. Exp. Appl. Acarol. 2018, 74, 301-315. [CrossRef]

243. Nazzi, F.; Milani, N. A Technique for Reproduction of Varroa jacobsoni oud under Laboratory Conditions. Apidologie 1994, 25, 579-584. [CrossRef]

244. Piou, V.; Tabart, J.; Urrutia, V.; Hemptinne, J.-L.; Vétillard, A. Impact of the Phoretic Phase on Reproduction and Damage Caused by Varroa destructor (Anderson and Trueman) to Its Host, the European Honey Bee (Apis mellifera L.). PLoS ONE 2016, 11, e0153482. [CrossRef]

245. Piou, V.; Tabart, J.; Hemptinne, J.-L.; Vétillard, A. Effect of Pollen Extract Supplementation on the Varroatosis Tolerance of Honey Bee (Apis mellifera) Larvae Reared in Vitro. Exp. Appl. Acarol. 2018, 74, 25-41. [CrossRef]

246. Bruce, W.A.; Henegar, R.B.; Hackett, K.J. An Artificial Membrane for in Vitro Feeding of Varroa jacobsoni and Acarapis woodi, Mite Parasites of Honey Bees. Apidologie 1991, 22, 503-507. [CrossRef]

247. Tabart, J.; Colin, M.-E.; Carayon, J.-L.; Tene, N.; Payre, B.; Vetillard, A. Artificial Feeding of Varroa destructor through a Chitosan Membrane: A Tool for Studying the Host-Microparasite Relationship. Exp. Appl. Acarol. 2013, 61, 107-118. [CrossRef] [PubMed]

248. Posada-Florez, F.; Sonenshine, D.E.; Egekwu, N.I.; Rice, C.; Lupitskyy, R.; Cook, S.C. Insights into the Metabolism and Behaviour of Varroa destructor Mites from Analysis of Their Waste Excretions. Parasitology 2019, 146, 527-532. [CrossRef]

249. Posada-Florez, F.; Ryabov, E.V.; Heerman, M.C.; Chen, Y.; Evans, J.D.; Sonenshine, D.E.; Cook, S.C. Varroa destructor Mites Vector and Transmit Pathogenic Honey Bee Viruses Acquired from an Artificial Diet. PLoS ONE 2020, 15, e0242688. [CrossRef] [PubMed]

250. Boot, W.J. Methyl Palmitate Does Not Elicit Invasion of Honey bee Brood Cells by Varroa Mites. Exp. Appl. Acarol. 1994, 18, 587-592. [CrossRef]

251. Rickli, M.; Guerin, P.M.; Diehl, P.A. Palmitic Acid Released from Honey bee Worker Larvae Attracts the Parasitic Mite Varroa jacobsoni on a Servosphere. Naturwissenschaften 1992, 79, 320-322. [CrossRef]

252. Light, M.; Shutler, D.; Cutler, G.C.; Hillier, N.K. Varroa destructor Mite Electrophysiological Responses to Honey Bee (Apis mellifera) Colony Volatiles. Exp. Appl. Acarol. 2020, 81, 495-514. [CrossRef]

253. Marchal, P.; Buatois, A.; Kraus, S.; Klein, S.; Gomez-Moracho, T.; Lihoreau, M. Automated Monitoring of Bee Behaviour Using Connected Hives: Towards a Computational Apidology. Apidologie 2020, 51, 356-368. [CrossRef]

254. Siefert, P.; Hota, R.; Ramesh, V.; Grünewald, B. Chronic Within-Hive Video Recordings Detect Altered Nursing Behaviour and Retarded Larval Development of Neonicotinoid Treated Honey Bees. Sci. Rep. 2020, 10, 8727. [CrossRef] [PubMed]

255. Siefert, P.; Buling, N.; Grünewald, B. Honey Bee Behaviours within the Hive: Insights from Long-Term Video Analysis. PLoS ONE 2021, 16, e0247323. [CrossRef]

256. Szczurek, A.; Maciejewska, M.; Bakk, B.; Wilk, J.; Wilde, J.; Siuda, M. Detecting Varroosis Using a Gas Sensor System as a Way to Face the Environmental Threat. Sci. Total. Environ. 2020, 722, 137866. [CrossRef]

257. Szczurek, A.; Maciejewska, M.; Zajiczek, Ż.; Bąk, B.; Wilk, J.; Wilde, J.; Siuda, M. The Effectiveness of Varroa destructor Infestation Classification Using an E-Nose Depending on the Time of Day. Sensors 2020, 20, 2532. [CrossRef] [PubMed]

258. Giuffre, C.; Lubkin, S.R.; Tarpy, D.R. Does Viral Load Alter Behavior of the Bee Parasite Varroa destructor? PLoS ONE 2019, 14, e0217975. [CrossRef] [PubMed]

259. Moro, A.; Mutinelli, F. Field Evaluation of Maqs ${ }^{\circledR}$ and Api-Bioxal ${ }^{\circledR}$ for Late Summer Control of Varroa Mite Infestation in Northeastern Italy. J. Apic. Res. 2019, 58, 53-61. [CrossRef]

260. Di Noi, A.; Casini, S.; Campani, T.; Cai, G.; Caliani, I. Review on Sublethal Effects of Environmental Contaminants in Honey Bees (Apis mellifera), Knowledge Gaps and Future Perspectives. IJERPH 2021, 18, 1863. [CrossRef] [PubMed]

261. DeGrandi-Hoffman, G.; Curry, R. A Mathematical Model of Varroa Mite (Varroa destructor Anderson and Trueman) and Honey bee (Apis mellifera L.) Population Dynamics. Int. J. Acarol. 2004, 30, 259-274. [CrossRef]

262. Ezanno, P.; Vergu, E.; Langlais, M.; Gilot-Fromont, E. Modelling the Dynamics of Host-Parasite Interactions: Basic Principles. In New Frontiers of Molecular Epidemiology of Infectious Diseases; Morand, S., Beaudeau, F., Cabaret, J., Eds.; Springer Netherlands: Dordrecht, The Netherlands, 2012; pp. 79-101, ISBN 978-94-007-2113-5.

263. Vetharaniam, I. Predicting Reproduction Rate of Varroa. Ecol. Model. 2012, 224, 11-17. [CrossRef]

264. Legg, D.E. The relevance of modelling in successful implementation of IPM. In Integrated Pest Management: Potential, Constraints and Challenges; Koul, O., Dhaliwal, G.S., Cuperus, G.W., Eds.; CABI: Wallingford, UK, 2004; pp. 39-54, ISBN 978-0-85199-686-8.

265. Calovi, M.; Grozinger, C.M.; Miller, D.A.; Goslee, S.C. Summer Weather Conditions Influence Winter Survival of Honey Bees (Apis mellifera) in the Northeastern United States. Sci. Rep. 2021, 11, 1553. [CrossRef] [PubMed]

266. Hopkins, S.R.; Fleming-Davies, A.E.; Belden, L.K.; Wojdak, J.M. Systematic Review of Modelling Assumptions and Empirical Evidence: Does Parasite Transmission Increase Nonlinearly with Host Density? Methods Ecol. Evol. 2020, 11, 476-486. [CrossRef]

267. Martin, S.J. The Role of Varroa and Viral Pathogens in the Collapse of Honey bee Colonies: A Modelling Approach: Collapse of Varroa-Infested Honey bee Colonies. J. Appl. Ecol. 2001, 38, 1082-1093. [CrossRef]

268. Ratti, V.; Kevan, P.G.; Eberl, H.J. A Mathematical Model of the Honey bee-Varroa destructor-Acute Bee Paralysis Virus System with Seasonal Effects. Bull. Math. Biol. 2015, 77, 1493-1520. [CrossRef] [PubMed]

269. Ratti, V.; Kevan, P.G.; Eberl, H.J. A Mathematical Model of Forager Loss in Honey bee Colonies Infested with Varroa destructor and the Acute Bee Paralysis Virus. Bull. Math. Biol. 2017, 79, 1218-1253. [CrossRef] [PubMed]

270. Betti, M.; LeClair, J.; Wahl, L.; Zamir, M. Bee++: An Object-Oriented, Agent-Based Simulator for Honey Bee Colonies. Insects 2017, 8, 31. [CrossRef] 
271. Bulson, L.; Becher, M.A.; McKinley, T.J.; Wilfert, L. Long-term Effects of Antibiotic Treatments on Honey bee Colony Fitness: A Modelling Approach. J. Appl. Ecol. 2021, 58, 70-79. [CrossRef] [PubMed]

272. Xu, X.; Zhao, P.; Wang, Z.; Zhang, X.; Wu, Z.; Li, W.; Tang, Y.; Liu, G. In Silico Prediction of Chemical Acute Contact Toxicity on Honey Bees via Machine Learning Methods. Toxicol. In Vitro 2021, 72, 105089. [CrossRef] [PubMed]

273. Karlsson Green, K.; Stenberg, J.A.; Lankinen, Å. Making Sense of Integrated Pest Management (IPM) in the Light of Evolution. Evol. Appl. 2020, 13, 1791-1805. [CrossRef]

274. Seeley, T.D.; Smith, M.L. Crowding Honey bee Colonies in Apiaries Can Increase Their Vulnerability to the Deadly Ectoparasite Varroa destructor. Apidologie 2015, 46, 716-727. [CrossRef] 